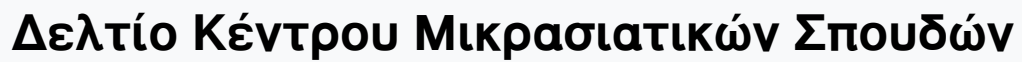

Tóp. 16 (2009)

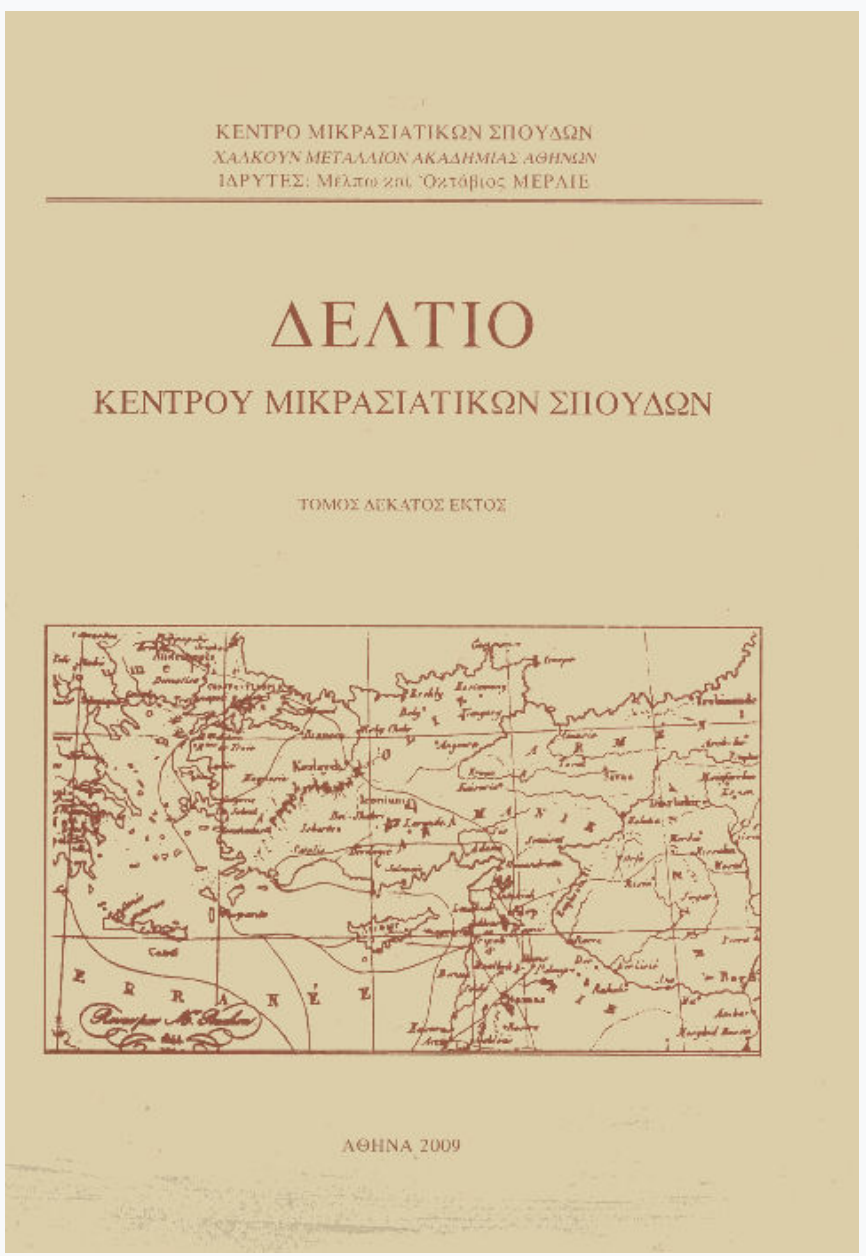

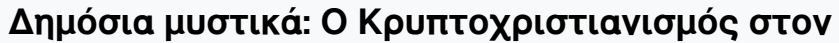 Пóvto}

Yorgos Tzedopoulos

doi: $10.12681 /$ deltiokms.15

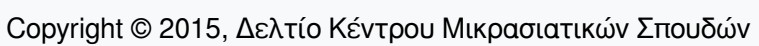

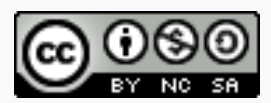

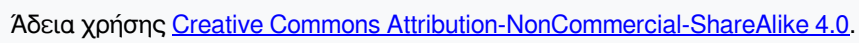

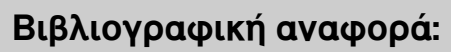

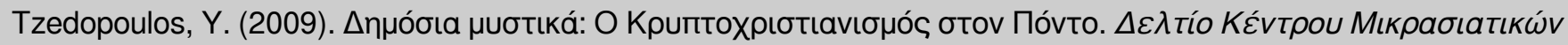

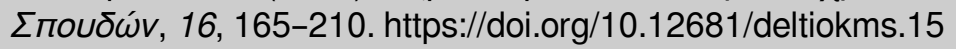


YORGOS TZEDOPOULOS

\section{PUBLIC SECRETS: CRYPTO-CHRISTIANITY IN THE PONTOS*}

In memory of Gunnar Hering

The term crypto-Christians, as concerns subjects of the Ottoman Empire, refers to populations that had supposedly once converted to Islam, either voluntarily or by force, but retained their Christian beliefs and practiced their Christian rites in secret. During the period of the Tanzimat reforms in the nineteenth century, which, among other things, granted religious freedom and made conversion possible, at least theoretically ', also for Muslims, some Muslim populations from Albania, Kosovo, Crete, and the Pontos on the Black Sea coast declared publicly that, since they were not Muslims in their hearts

* This article originated in a paper presented at the Workshop Local and Imperial Approaches to Ottoman/Greek Social History organized by the Program in Hellenic Studies, Princeton University. The Workshop was held in the Historical Archive of Samos in September 12-16, 2001, only one day after the attack of 9/11. I wish to thank from all my heart Christine Philliou, the organizer of the workshop, and all the participants, especially those who came from the USA, for not allowing the shadow of terror and fanaticism to mar their critical attitude in the analysis of past or present societies. The companionship that prevailed among people with different ethnic and national backgrounds, as well as the fruitful and reflective discussions that took place, were accompanied by the consciousness of the historian's political and social responsibility. Gunnar Hering would have appreciated this commitment.

1. In a ferman issued in March 1844, the Porte declared that it would see to it that converts from Islam to Christianity would no longer be executed as apostates. The ferman was the result of strong diplomatic pressure from the British ambassador to the Porte Stratford Canning. See Turgut Subaş1, "The Apostasy Question in the Context of Anglo-Ottoman Relations, 1843-44", Middle Eastern Studies 38/2 (April 2002), pp. 1-34. 
and since they had been practicing their ancient faith, Christianity, for many years in secret, they wished to become officially acknowledged as Christians ${ }^{2}$.

One of these populations was the Greek-speaking Kromlides of the Pontos, who in 1857 declared their Christian identity and demanded to be recognized by the authorities as Orthodox Christians. Kromlides lived in the Eastern Pontos, in settlements that lay mostly in the mountainous area between Trebizond and Gümüşhane (Greek: Argyroupolis) and belonged partly to the kaza of Trebizond and partly to that of Torul. Most of them originated from the region of Kromni (Turkish: Kurum) ${ }^{3}$, after which they had acquired the collective name Kromlides (Turkish: Kurumlu) ${ }^{4}$. They were

2. For a recent overview of crypto-Christianity and crypto-Judaism see Maurus Reinkowski, "Kryptojuden und Cryptochristen im Islam", Saeculum 54 (2003), pp. 13-37. On crypto-Christianity in the Balkans see Stavro Skendi, "Crypto-Christianity in the Balkan Area Under the Ottomans", in Stavro Skendi, Balkan Cultural Studies, New York 1980, pp. 233-257 (originally published in Slavic Review 26 [1967], pp. 227-246). On Albania see Peter Bartl, Kryptochristentum und Formen des religiösen Synkretismus in Albanien, Munich 1967. On the region of Spathia (Albanian: Shpati)

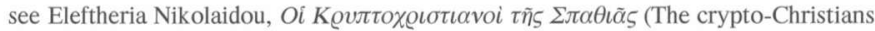
of Spathia), Ioannina 1979. On Kosovo see Ger Duijings, Religion and the Politics of Identity in Kosovo, London 2000, pp. 10-15, $90-96$ (quoted in Reinkowski, op.cit.), and Noel Malcolm, "Crypto-Christianity and Religious Amphibianism in the Ottoman Balkans: the Case of Kosovo", in Celia Hawkesworth - Muriel Heppel Harry Norris (eds), Religious Quest and National Identity in the Balkans, New York

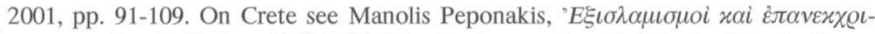

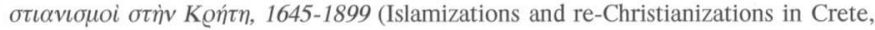
1645-1899), Rethymnon 1997, pp. 77-83.

3. See the two lists of the settlements and numbers of the Kromlides from 1857 , published in Antony Bryer, "The crypto-Christians of the Pontos and Consul Wil-

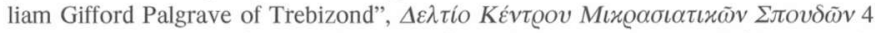

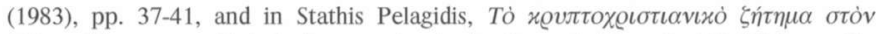
Пóvto (The crypto-Christianity question in the Pontos), Thessaloniki 1996, pp. 6167. The second list has also been published in Artemis Xanthopoulou-Kyriakou (ed.),

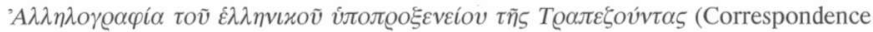
of the Greek vice-consulate of Trebizond), vol. I (1839-1858), Athens 1995, pp. 415418. The lists were given by the clerks of the Kromlides to the British and the Greek consuls respectively, who attached them to their reports. They show only a few differences of no particular importance.

4. After 1857 the term was often used as a pars pro toto for all crypto-Christians of the Pontos, except for the Stavriotes from the region of Akdağ. It shall be used in this sense here. 
also called $k l o s t o i^{5}$ and $k r y f o i$ (the hidden or secret ones) and were known to be Muslims who followed Christian religious practices.

Here we shall venture to trace the genesis and the evolution of the crypto-Christian issue in the Pontos from 1857 until the exchange of populations between Greece and Turkey in the 1920's. We shall focus our attention on the emergence of crypto-Christianity as a collective action, as an interpretational tool, as a political argument, and as a way to imagine the history of the Orthodox of Asia Minor.

\section{The crypto-Christianity narrative}

The crypto-Christianity narrative has become dominant in Greek national historiography with regard to Islamization, identity, and religious syncretism in the Ottoman Empire. This interpretation of conversion was formed at the end of the 19th century and was consolidated at the beginning of the 20th century through the interaction of four main factors: Muslim conversion to Christianity, nationalism, ethnography, and politics. National discourse elaborated on the distinction between "true" and "false" identity made by converts to Christianity; ethnography revealed religious practices and beliefs that did not conform to Orthodox Sunni Islam, and often ascribed them to a Christian past or influence ${ }^{6}$; lastly, political instrumentalization of cryptoChristianity legitimized national aspirations.

5. The term klostoi, which means "turned" in Pontic Greek, is undoubtedly a translation of the Ottoman Turkish dönme, and as such hints at a prior Islamization. The term dönme is mostly used in connection to the Jews who converted to Islam after the failure of Sabbatai Sevi's messianic movement in the 17th century and were known as Judaizing Muslims. It is more than probable, however, that the term was used as collective term for cases of mass conversions to Islam. For instance, the converts to Islam during the plunder of Chios by the Ottomans in 1822 were also called dönme (Greek:

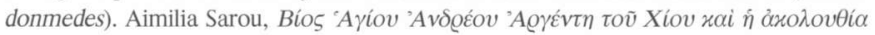
$\alpha \tilde{u} \tau o \tilde{v}$ (Vita and mass of St Andrew Argentis of Chios), Athens 1935, pp. 123-124.

6. On the uses of ethnography in the Balkans and Asia Minor see above all the contributions in David Shankland (ed.), Anthropology, Archaeology and Heritage in the Balkans and Anatolia: The Life and Times of F. W. Hasluck (1878-1920), 2 vols, Istanbul 2003, particularly David Barchard, "Modernity, Muslims and British Archaeologists: Michael Gough at the British Institute of Archaeology in Ankara and his Predecessors", vol. 1, pp. 257-280, and İpek Yosmaoǧlu, "Field of Dreams: Ethnographical Maps and the Ethne of Macedonia, 1842-1906”, vol. 2, pp. 269-298. 
The crypto-Christianity narrative that emerges is structured on a pattern that evolves over time as a story with a beginning and an end: "superficial" conversion to Islam; secret, "private" practice of the old ways under the "public" mask of Islam; and teleological return to the "true" faith. This interpretation, incorporating to a different extent the theological notions of fall, shame, perseverance, resistance, and resurgence, focuses on identity and continuity: the heroes of the story, those Christian communities turned Muslim turned Christian, remain the same despite adversities and necessary disguises. Needless to say, this "sameness" is perceived not only as religious and cultural but also as national; in the specific historical and geopolitical context, Greek national discourse equated crypto-Christianity with crypto-Greekness?

Despite its ideological coherence (or because of it), this interpretation is highly problematic. Islamization was a formal act that carried with it a whole set of regulations changing abruptly the socio-political status of the individual; conversion to Islam could not be conceived but in absolute terms. The cryptoChristians did not simply pass for Muslims; they were so, since their sociopolitical identity was Muslim, regardless of their deviating religious practices ${ }^{8}$.

Moreover, the distinction between true/private and false/public identity has several methodological flaws, since it approaches identity in an essentialist and monolithic way. Identity is not an inner, metaphysical quality but a social category formed by interaction and negotiation ${ }^{9}$. Identity -or rather identities- are constantly re-interpreted, re-applied, and re-negotiated. In the words of Charles Tilly, identity "is not private and individual but public and relation$\mathrm{al} ;[\ldots]$ any actor deploys multiple identities, at least one per category" ${ }^{10}$.

The multiple identities of the so-called crypto-Christians in the Ottoman Empire applied to different social environments. As far as our sources permit us to discern, the same people defined themselves as Muslims or Christians in different situations and for different reasons. There is hardly any doubt that the eighteenth-century sipahis from Epirus as well as the Krom-

7. Even the Albanian-speaking Spathiotes were often held to be Greeks. Nikolaidou, op.cit., pp. 97-104.

8. See Selim Deringil, “'There Is No Compulsion in Religion': On Conversion and Apostasy in the Late Ottoman Empire: 1839-1856", Comparative Studies in Society and History 42:3 (July 2000), p. 548.

9. Richard Jenkins, Social Identity, London-New York 1996, pp. 19-28.

10. Charles Tilly, "Citizenship, Identity and Social History", in Charles Tilly (ed.), Citizenship, Identity and Social History, Cambridge 1996, p. 7. 
lides of the mid-nineteenth century, both of whom identified themselves as Christians in front of European witnesses ", put forth their Muslim identity when it came to paying taxes or to reassuring their social superiority over their Christian neighbours. In terms of identity internalization, it is indicative that the Spathiotes of Albania who, like the Pontic Kromlides, bore two names, a Muslim and a Christian, called the first their "big" and the latter their "small" name ${ }^{12}$; multiple does not mean equally important.

It is also in terms of social interaction that we should understand the secret character of crypto-Christianity. As Louise White suggests, the meaning and value of secrets "change and are negotiated and renegotiated regular1y. Secrets and secrecy are social acts, constantly aware of audiences and publics $[\ldots]$. When we realize how poorly secrets are kept, how selective and managed tellings 'leak' information to a wide variety of audiences, it seems clear that secrets ironically are ways of making information known" ${ }^{13}$. Thus it should not seem surprising that the authorities and the people of Trebizond where not startled when in 1857 some 17,000 Kromlides declared their "return" to Christianity ${ }^{14}$.

Of course, the deviant religious practices of those villagers, who, according to the British consul in Trebizond, were seen as being "neither Mussulmans nor Christians" ${ }^{15}$; were not to be officially accepted. Socio-cultural realities, however, were open to negotiation, and eventual contradictions were tacitly tolerated. Unlike the Shiite Kızılbas, who had challenged the legitimacy of the Sultan's power in the sixteenth century ${ }^{16}$, religiously

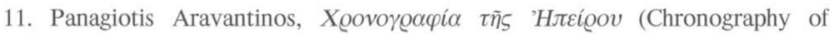
Epirus), vol. 1, Athens 1856, p. 227; P. Tchihatcheff, Lettres sur la Turquie, BruxellesLeipzig 1859, p. 20.

12. Nikolaidou, op.cit., pp. 130-144.

13. Louise White, "Telling More: Lies, Secrets, and History", History and Theory 39 (2000), p. 22.

14. As to the total number of the Kromlides see Bryer, "The crypto-Christians", pp. 37-41, and Pelagidis, op.cit., pp. 61-67.

15. Bryer, "The crypto-Christians", p. 35. Compare Byron's remark on the Albanians: "the Greeks hardly regard them as Christians, or the Turks as Moslems; and in fact they are a mixture of both, and sometimes neither." George Gordon Lord Byron, Childe Harold's pilgrimage. A romaunt and other poems, London ${ }^{4} 1812$, p. 139.

16. See Colin Imber, "The Persecution of the Ottoman Shī'ites According to the Muihimme Defterleri, 1565-1585", in Colin Imber, Studies in Ottoman History and Law, Istanbul 1996, pp. 103-128. 
deviant populations (like the Judaizing dönme) were as a rule not persecuted in the Ottoman Empire. As long as they fulfilled their obligations vis-à-vis the state, kept a low profile and did not cause scandal among their more orthodox neighbours, they were left more or less free to live in blasphemy ${ }^{17}$. Contrary to Western and Central European rulers during the early modern period, the Ottomans made no serious attempt to suppress or "reform" popular culture ${ }^{18}$, apart from the short-lived success of "fundamentalist" movements like the kadizadelis in the seventeenth century ${ }^{19}$.

17. See Reinkowski, op.cit., pp. 27-30. Of course, open denial or revilement of Islam was a different matter. The rejection of Islam by Islamized Christians was a crime punished according to Islamic law by death. Executed apostates sometimes acquired the status of neo-martyrs among Christians. The vitae of neo-martyrs, however, indicate that their cases were not brought before the court by officials wishing to correct the subjects' religious attitudes; on the contrary, the apostates were accused by former friends, neighbours, colleagues, people who expected to profit from their death, or over-zealous Muslims. Some of them even appeared at court without having being accused, and declared their return to Christianity in order to acquire the "wreath of martyrdom". It is indicative that the Ottoman judges, the kadis, wishing to avoid public commotion, are often reported in the vitae as urging the prospective martyrs to escape immediate danger by declaring their faith to Islam and to continue practicing crypto-Christianity in private. On Orthodox neomartyrs in the Ottoman Empire see Elizabeth Zachariadou, "The Neomartyr's Mes-

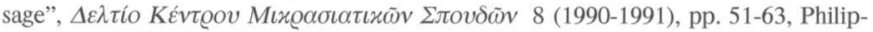

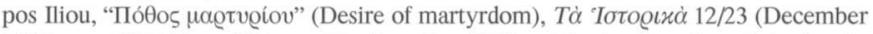

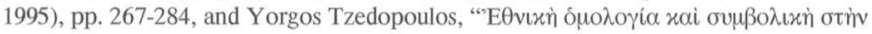

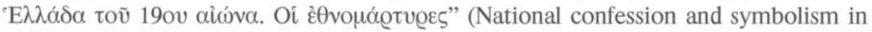
19th-century Greece: the national martyrs), Mví $\omega \omega v 24$ (2002), pp. 107-116. See also Rossitsa Gradeva, "Apostasy in Rumeli in the Middle of the Sixteenth Century", Arab Historical Review for Ottoman Studies 22 (September 2000), pp. 29-73; see also: Eleni Gara, "Neomartyr without a Message"; Phokion Kotzageorgis, "“Messiahs' and Neomartyrs in Ottoman Thessaly: Some Thoughts on Two Entries in a Muihimme Defteri”; Marinos Sariyannis, "Aspects of 'Neomartyrdom': Religious Contacts, 'Blasphemy' and 'Calumny' in 17th-Century Istanbul”; all three in Archivum Ottomanicum 23 (2005-2006) [Mélanges à l'honneur d'Elizabeth A. Zachariadou, ed. György Hazai], pp. 155-175, 219-231, and 249-262 respectively.

18. On Western and Central Europe see Peter Burke, Popular Culture in Early Modern Europe, London ${ }^{2} 1994$. On the Ottoman Empire see Selim Deringil, The Well-Protected Domains: Ideology and Legitimacy of Power in the Ottoman Empire, 1876-1909, London-New York 1999, especially pp. 68-92.

19. On the kadizadelis see Madeline Zilfi, The Politics of Piety: The Ottoman Ulema in the Postclassical Age (1600-1800), Minneapolis 1988. 
Lastly, we should bear in mind that a kind of secretive behaviour was the rule in the dealings of Ottoman subjects with the state, particularly in the countryside. The peasant and pastoralist communities of the Empire, Muslim and non-Muslim alike, tried to avoid attracting the attention of Ottoman authorities and power holders as much as possible. Villages disappeared suddenly in order to escape taxation, farmers hid their crops, heterodox Muslims did not reveal their beliefs and practices in front of strangers, and every effort was made to escape conscription. Therefore, the fact that Muslims who followed Christian rites took particular care to hide their practices should not strike us as exceptional ${ }^{20}$. There can be no doubt that they, as heterodox Muslims, had to present "themselves as official Muslims when it came to their dealings with the state" ${ }^{21}$.

\section{Who were the Kromlides?}

Most scholars have placed the incipience of crypto-Christianity in the Pontos within the framework of a conversion wave in the second half of the seventeenth century ${ }^{22}$, which is seen as a result of the "usurpation" of state power

20. During the census of the Greek-Orthodox Ottoman population of 1910-1912 that was carried out by the Greek consulates in cooperation with the authorities of the Orthodox church, "the census committees of the archbishopric of Trebizond found it extremely difficult to penetrate and overcome the suspicions of the cryptoChristian Black Sea villages." Alexis Alexandris, "The Greek Census of Anatolia and Thrace (1910-1912): A Contribution to Ottoman Historical Demography”, in Dimitri Gondicas - Charles Issawi (eds), Ottoman Greeks in the Age of Nationalism: Politics, Economy, and Society in the Nineteenth Century, Princeton 1999, pp. 65-66.

21. Michael Meeker, A Nation of Empire. The Ottoman Legacy of Turkish Modernity, Berkeley and Los Angeles 2002, p. 162.

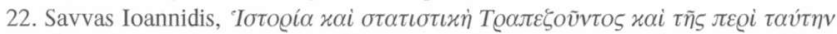

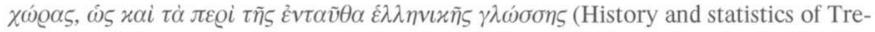
bizond and the surrounding areas), Istanbul 1870, p. 118; Epameinondas Kyriakidis,

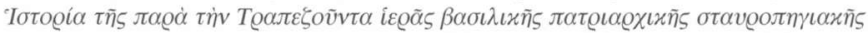

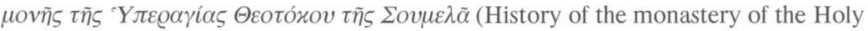
Virgin of Soumela near Trebizond), Athens 1898, p. 91; R. Janin, "Musulmans malgré eux: Les Stavriotes", Échos d'Orient 15 (1912), p. 497; R. Dawkins, "The cryptoChristians of Turkey", Byzantion 8 (1933), pp. 258-259. This opinton is also held by several contemporary Greek historians, like Kostas Photiadis, Oi $\hat{\varepsilon} \xi \iota \gamma \lambda \alpha \mu \iota \mu o i$ iñ

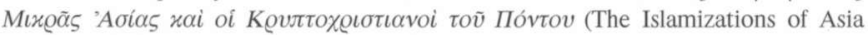
Minor and the crypto-Christians of the Pontos), Thessaloniki 1993, p. 214 ff. 
by powerful local Muslim families, the so-called "lords of the valley" (derebeys). Indeed, the rise of the derebeys meant that powerful Muslim families had the chance to participate in local politics and resource exploitation, as well as to form power alliances. Thus, Islamization became for some Christians a means to acquire social status, wealth and power. It is striking that in 1857 many Kromlides had family names with the characteristic -oğlu or -zade suffix, used by prominent families of elite status, while some bore the title of aga $^{23}$. Indeed, as a writer from Kromni put it, the derebeys of Kromni consisted by no other than the local Islamized families ${ }^{24}$.

Anthony Bryer has proposed a subtler interpretation that focuses on the Pontic miners ${ }^{25}$. According to Bryer, the miners, as a group that fulfilled special functions vis-à-vis the state, were exempt from all tax obligations (including the poll-tax levied on non-Muslims), while as Christians they were free from military service. After the failing of the Gümuishane mines, he argues, the miners tried to retain both privileges by passing as Muslims around the late 1820 s and by declaring themselves Christian in 1857. On the last occasion they demanded military exemption, while simultaneously refusing to pay the bedel-i askeri, the tax levied on non-Muslims in lieu of military service ${ }^{26}$.

Hasluck, on the other side, links crypto-Christianity to "outbursts of anti-Christian fanaticism in the sixteenth and seventeenth centuries", F. W. Hasluck, "The cryptoChristians of Trebizond", The Journal of Hellenic Studies 41:2 (1921), p. 200.

23. Compare the names of the representatives of the Kromlides in their petition from 1857, published in Chrysanthos [Philippidis], Metropolitan of Trebizond, " $\mathrm{H}$

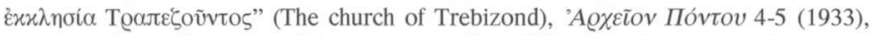
pp. 717-719. On the names of the prominent Kromlides from the region of Stavri see

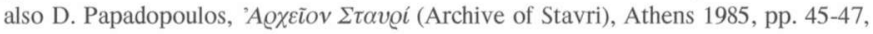
50-51, 58-60, 65-67.

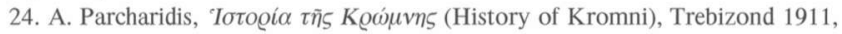
p. 43.

25. The argentiferous lead mines of the region of Gümushhane operated from the 16th century and played an important role in the economy of the area. On the mines see Anna Ballian, "Argyroupolis - Gümüşhane: Mining Capital of Pontos", in Marianna Koromila (ed.), The Greeks and the Black Sea from the Bronze Age to the Early 20th Century, Athens 2002, pp. 338-349, as well as pp. 459-460 for an extensive annotated bibliography.

26. Bryer, "The crypto-Christians", pp. 30-33. Apart from being a delightful piece of prose, Bryer's article stands out as a very thought-provoking contribution to the interpretation of crypto-Christianity in the Pontos. Bedel-i askeri replaced 
Bryer is surely right in establishing a link between the Kromlides and the mining economy. Many of the Kromlides of 1857 lived in settlements that were or had been important mining centres, like Kromni, Santa (Turkish: Dumanhi), and Stavri (Turkish: Ístavri) ${ }^{27}$. However, the miners' status was less ambivalent: the Christians among them were indeed exempt from various tax burdens and obligations, but not from the poll tax ${ }^{28}$. It is intriguing as to why some members of this "privileged" social group resorted to Islamization. The answer, however, would require detailed research into Ottoman sources, which has not been done for the period after the sixteenth century ${ }^{29}$. It is probable that the mining society and economy was more a factor of the perpetuation - and re-negotiation - of double identities than of their genesis. As to the crisis that followed the closure of the Guimisşane mines, many miners then became dependant on the mines of $\mathrm{Kromni}^{30}$, which remained in operation until 1854-1855 ${ }^{31}$. I suggest that it was their failure that was decisive for the collective action of 1857.

cizye after 1856. H. Bowen, "Bedel”, Encyclopédie de l'Islam, vol. I, Leiden 1991, p. 878 .

27. According to the 1857 catalogue of the settlements of the Kromlides, Kromni, Santa and Stavri accounted for more than $22 \%$ of the Kromlides, while other settlements that figure in the catalogue, for instance Poulantzaki (Turkish: Bulancak) and Tzanchraki (Turkish: Çakrak) in the kaza of Giresun (Greek: Kerasounta), had been established as "mining colonies". Bryer, "The crypto-Christians", pp. 33, 37-41.

28. A. Refik, Osmanlı devrinde Türkiye madenleri (967-1200), Istanbul 1931, pp. 172, 177-178. I thank Ioannis Karachristos and Seyyid Mohammad Shariat Panahi for this information. Bryer, "The crypto-Christians", p. 32, argues that the miners "were excused harac [i.e. poll tax] in return for mining or charcoal service". In fact, the miners of Santa paid the poll tax and their other taxes in kind (charcoal loads). After the

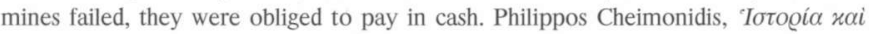

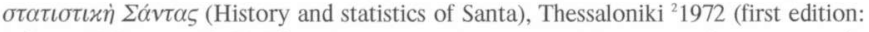
Athens 1902), pp. 92-93. The miners were almost certainly exempt from extraordinary taxes. See Rhoads Murphey, "Ma'din: Exploration minière dans l'empire ottoman”, Encyclopédie de l'Islam, vol. V, Leiden 1986, pp. 977-978.

29. For the 15 th and 16 th centuries see Heath Lowry, The Islamization and Turkification of Trabzon, 1461-1483, Istanbul 1981; and Heath Lowry, "Privilege and Property in Ottoman Maçuka in the Opening Decades of the Tourkokratia: 1461-1553", in Anthony Bryer - Heath Lowry (eds), Continuity and Change in Late Byzantine and Early Ottoman Society, Birmingham-Washington D.C. 1986, pp. 97-128.

30. Cheimonidis, op.cit., p. 93.

31. Ibid., p. 93; Parcharidis, op.cit., p. 48. 
Another important sector of the economy of the eastern Pontos was pastoralism $^{32}$. Since the conflicts between village communities or between village communities and Turkmen tribes for the summer pastures (Turkish: yayla, Pontic Greek: parcharia) were not uncommon ${ }^{33}$, small-scale mass conversion to Islam could have served as an advantage in the struggle to capture the best pasture ${ }^{34}$. At the same time, conversion was not simply a family and community strategy: Islamization could effectively split a kin or a complex household that had been driven in internal strife, while it placed simultaneously the converts in an advantageous position ${ }^{35}$.

Islamization was without doubt facilitated by widespread syncretism, which in turn was reinforced by new conversions ${ }^{36}$. It is well known that

32. On the ecology and the economy of the "valley systems" of Eastern Pontos see Meeker, op.cit., pp. 85-109. On the region of Matsouka south of Trebizond (Turkish: Maçka) see Anthony Bryer, "Rural Society in Matzuka", in Bryer Lowry, op.cit., pp. 55-62.

33. These "almost annual battles for the high summer grazing pastures" between "the Greeks of the coast and the more purely transhumant peoples of the interior", Laz or Turkmen, constituted a longue durée in the Pontos. Anthony Bryer, "Some Notes on the Laz and Tzan I", in Anthony Bryer, Peoples and Settlement in Anatolia and the Caucasus, London 1988, XIVa, p. 180.

34. According to an interpretation of the Islamization process in the region of Santa, around 1730 the community decided that a significant number of the population would have to covert to Islam in order to protect the communal rights over a summer pasture that was contested by a nearby village. Cheimonidis, op.cit., pp. $57-$ 59. Regardless of the truth of this story, which may have been invented in order to present the converts in a favourable light, it would be a mistake to dismiss the conversion motive per se as unimportant.

35. D. Papadopoulos, op.cit., pp. 67-68. Undoubtedly conversion affected - and was affected by - family and community structure. As a rule, Pontic society in the countryside was organised in complex patrimonial families that often comprised

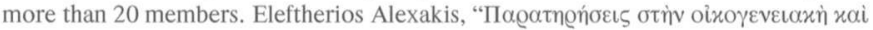

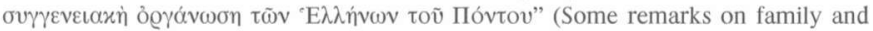

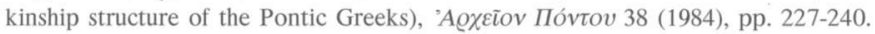
The concentration of power over a large household, the strict hierarchical relationships between family members and the existence of large kinship networks minimized individual choices and facilitated the evolution of effective strategies. Thus, conversion could take the form of a minor mass Islamization. At the same time, however, conversion could effectively destroy community and kinship ties, something that could not easily be achieved otherwise. Ibid., p. 231.

36. For contemporary accounts of syncretistic practices in other regions of the 
many Muslims participated in the local Christian pilgrimage to the Panagia Soumela monastery ${ }^{37}$. Indeed, some of the nineteenth-century Kromlides were reportedly not descendants of converts to Islam but of Muslims (often of Turkmen origin) who had been linguistically Grecisized and practiced a syncretistic form of Christianity ${ }^{38}$.

It is certainly true that the Kromlides of 1857 constituted a social group, at least by virtue of their collective action; yet it would be a mistake to assume that they had necessarily been so in the past. I suggest that, when the mining economy of Kromni collapsed, a part of this "pool" of former converts to Islam and Christianizing Muslims opted for Christianity. It was the former miners of Kromni that took the initiative; however, many of the people that lined up with them probably had other backgrounds, while others, who in theory could have taken part in the movement of 1857 , did not do so for various reasons. But, regardless of whether the Kromlides of 1857 had diverse origins, it is now time to turn to their motives and follow their adventures.

Empire with crypto-Christian populations compare Aravantinos, op.cit., p. 246, and Robert Pashley, Travels in Crete, vol. 1, London 1837, p. 194. For a general view of syncretism in the Ottoman empire see above all F. W. Hasluck, Christianity and Islam under the Sultans, 2 vols., Oxford 1929, as well as the contributions in Shankland (ed.), Anthropology, Archaeology and Heritage, particularly Galia Valtchinova, "Christian-Muslim Religious Symbiosis According to Hasluck: Comparing two Local Cults of Saint Therapon", vol. 2, pp. 159-181.

37. Bryer, "The crypto-Christians", p. 23.

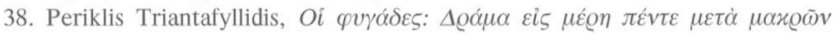

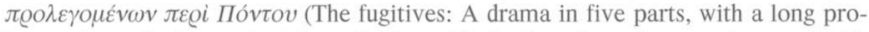
logue about the Pontos), Athens 1870, p. 92; D. Papadopoulos, op.cit., pp. 48-49, 58-59. Papadopoulos, op.cit., p. 47, mentions a certain Hasan Çavuş, the son of a Christianized Turkmen from Stavri, who "did not belong to a certain confession" and was wont to ask: "What is the difference between a Muslim (Tourkos) and a Christian (Romaios)? God is for everybody". According to Parcharidis, op.cit., p. 40, Kromni had attracted not only Christian but also Kızılbaş, Kurdish, Circassian and Turkmen immigrants. Since by 1857 Kromni was inhabited only by Christians and Kromlides, we can assume that at least some of the latter were the descendants of Muslims. As concerns the region of Santa, see also Anthony Bryer, "NineteenthCentury Monuments in the City and Vilayet of Trebizond: Architectural and Histor-

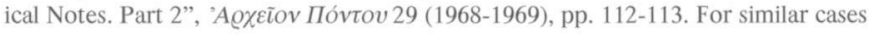
in Crete see Peponakis, op.cit., pp. 121-122. 
Kromlides and Stavriotes in the late Ottoman Empire

"After the failing of the mines [of Kromni], the kryfoi of Kromni, seeing no more profit in being Muslim, wishing also to avoid military service, and putting much hope on the Hatt-i Hümayun that affirmed freedom of religion, dared cast aside the mask of Islam and presented themselves to the world as Christians" ${ }^{39}$.

There is little to add to this lucid formulation of Parcharidis. The Kromlides' immediate concern was in all probability to avoid military service, which had recently become compulsory for Muslims through universal conscription ${ }^{40}$ and to which they were now exposed due to the loss of their miners' status. In this the Kromlides followed the example of the Spathiotes, another population of Christianizing Muslims who in 1846/1847, when the conscription law was implemented in Albania, had declared that they were not Muslims but Christians ${ }^{41}$.

This is not the place to emphasize the importance of universal conscription in the nation-building process and particularly in the Ottoman Empire. The generalization of conscription during the Tanzimat period not only dealt a serious blow to established social and economic practices, especially in the countryside; more than that, it represented an aspect of an unprecedented control over society by the state ${ }^{42}$. However, an interpretation of the Kromlides' declaration of Christianity as the reaction of a "traditional society" against the encroachment of the "modernizing state" would be misleading.

39. Parcharidis, op.cit., p. 49.

40. The army regulations that included universal conscription were promulgated in 1843. The conscription system was established in detail in 1848. Erik-Jan Zuircher, "The Ottoman Conscription System in Theory and Practice", International Review of Social History 43:3 (1998), pp. 439-440.

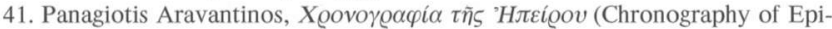
rus), vol. 2, Athens 1857 , p. 160. For a precise chronological account of their collective action see Nikolaidou, op.cit., pp. 158-159.

42. See Jan Lucassen - Erik-Jan Zürcher, "Conscription as Military Labour: The Historical Context”, International Review of Social History 43:3 (1998), pp. 405 419. On conscription and the building of a modern centralized army in the Middle East see Erik-Jan Zürcher (ed.), Military Conscription in the Middle East and Central Asia 1775-1925, London-New York 1999. 
The 1857 petition of the Kromlides to the Powers was "traditional" neither in discourse nor as a course of action:

"We depute these gentlemen [the Kromlides' representatives] by our firm and common decision to effect by the way they deem appropriate the disclosure of our up to the present hidden from the Ottomans Christian Orthodox religion. Hence, we plead their Excellencies the ambassadors of the imperial Powers of England, France, Austria, Russia, and Greece [...] to lead them [the representatives] into doing what is necessary for our religion and freedom" ${ }^{43}$.

The Kromlides' definition of their own identity was based on a liberal principle, namely religious freedom. One would be inclined to see behind the words the mediation of literate people who "translated" the Kromlides" demands into an idiom that could not fail to attract the attention of "civilized" Europeans ${ }^{44}$. While this is true, it does not affect the argument. The universal discourse on human rights was not confined to educated elites, but was offered as a conceptual and operational tool to various social groups. In claiming the right to define themselves in accordance with modern criteria and in staging their demonstration to the Ottoman - and European Public $^{45}$, the Kromlides re-invented themselves. Thus, from a blurred sociocultural landscape of multiple identities a collective political action emerged, which was well embedded in modernity. The appeal of the Kromlides to the European powers shows a clear awareness of the international politics of the time: neither their choice, nor the order in which the names of the Powers appear in the petition were accidental ${ }^{46}$.

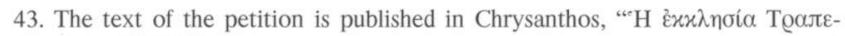
รoũvนoร", pp. 717-719.

44. Among these mediators were the secretary of the Russian consulate in Trebizond, who composed petitions for the Kromlides, and probably the teacher Periklis Triantafyllidis. Ioannidis, op.cit., p. 144; Periklis Triantafyllidis, $H$ żv $\Pi o ́ v \tau \omega$

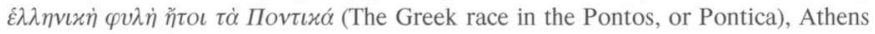
1866 , p. 94.

45. About the late Ottoman Empire being exposed to the view of the "West" and

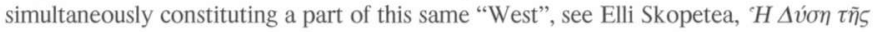

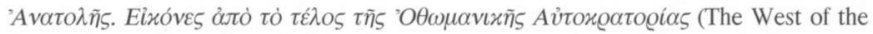
Orient: Images from the end of the Ottoman Empire), Athens 1992, pp. 41-49.

46. First come the victors of the Crimean War, with England, the principal advo- 
Indeed, a decisive factor in the Kromlides' profession of Christianity was the reshaping of the Eastern Question after the Crimean War. The Hatt-i Hümayiin of 1856 made clear not only the decision of the Sultan to follow further the dubious road of reform, but also the will of the Powers to observe closely the modernization process in the Empire. The position of the Christian subjects of the Porte had been the main legitimizing argument of Orthodox Russia in its frequent struggles with the Empire. Now, according to the Treaty of Paris, the Ottomans were liable to all the powers for their treatment of their Christian subjects ${ }^{47}$. Moreover, the defeated Russians would more than welcome a chance to regain their prestige, by presenting themselves as the par excellence friends and protectors of the Ottoman Christians.

Such considerations were based not on abstractions and generalities but on power relations which were clearly visible at the local level. Trebizond was not only the seat of an Ottoman vali but also of European consuls; the latter could - and did - influence the Ottoman decision-making process to the benefit of Christians, since the legitimacy of the Powers' intervention in Ottoman affairs passed largely through their assuming the role of protectors of the Empire's Christian subjects. In their turn, the Christians could quite often manipulate the rivalry between the Powers to promote their objectives ${ }^{48}$.

Among the Powers, Russia was particularly important for the Kromlides. The Russian army had invaded the Pontos in 1829; furthermore, its advance through the Caucasus had sent thousands of Tatar and Circassian refugees to practically every corner of the Ottoman Empire ${ }^{49}$. Christianity seemed to

cate and instigator of Ottoman reforms, at the first place, while Russia and Greece are mentioned at the end, probably in order to disperse the suspicion that the Kromlides' move was due to Russian initiative or had nationalistic motives. The Ottomans are mentioned only once and as if the matter did not actually fall within their jurisdic-

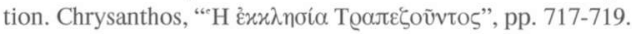

47. M. S. Anderson, The Eastern Question 1774-1923, New York 1966, p. 143.

48. When, in 1857 , the Russian consul in Trebizond promised to facilitate the migration of some Christian villagers from Santa to Russian territory, the English consul hastened to help the Christians in their struggle against the Muslims of Mesehor (Greek: Mesochori) about a contested summer pasture. Bryer, "The cryptoChristians", pp. 42-44.

49. See Kemal Karpat, "Population Movements in the Ottoman State in the Nineteenth Century: An Outline", in Jacques Bacqué-Grammont - Paul Dumont 
gain the upper hand in the Black Sea region ${ }^{50}$. Moreover, the Pontic Christians had close economic ties with Russia; they constituted an important link in the commercial networks along the Black Sea coast. The Russian territories in the Crimea and the Caucasus attracted many Pontic Christians ${ }^{51}$, the more so since Russians were encouraging the immigration of Ottoman Christians in the place of Tatar and Circassian refugees ${ }^{52}$. For the former miners migration could be an attractive alternative. Lastly, the Kromlides could profit from Russian largesse in granting passports to Pontic Christians, who by this means could claim the status of a foreign subject ${ }^{53}$.

The staging of the Kromlides' action made the issue too blatant to pass unnoticed. A committee consisting of representatives of the European embassies and Ottoman officials arrived in Trebizond and undertook to examine the issue and record the petitioners ${ }^{54}$, some of whom were recognized as Orthodox Christians in $1859^{55}$. However, turning Christian in the nineteenth-century Ottoman Empire was not simply a case of religious choice but an extremely politicized action. It was perceived as the convert's taking sides in a dilemma that would ultimately define the fate of the Empire. As Selim Deringil put it, "what was at issue was not religion at all, but sover-

(eds), Contributions à l'histoire économique et sociale de l'Empire ottoman, Leuven 1983, pp. 400-411.

50. Chrysanthos Filippidis, metropolitan of Trebizond and later archbishop of Athens, relates that in 1917, during the Russian occupation of the Pontos, some of the Greek-speaking Muslims from Of, who were descendants of Islamized Christians, hinted to him that they would eventually be willing to convert to Christianity.

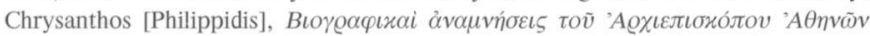

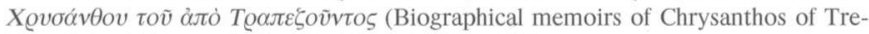
bizond, Archbishop of Athens), Athens 1970, p. 160.

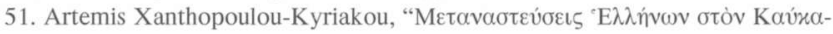

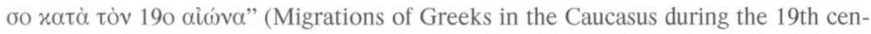

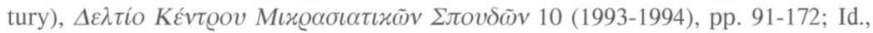
"The Diaspora of the Greeks of The Pontos: Historical Background", Journal of Refugee Studies 4:4 (1991), pp. 357-363.

52. Kemal Karpat, Ottoman Population 1830-1914. Demographic and Social Characteristics, London 1985, p. 68.

53. Bryer, "The crypto-Christians", pp. 36, 45 (footnote 68), 47.

54. Ioannidis, op.cit., p. 145.

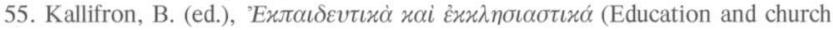
issues), Istanbul 1867 , p. 161. According to Kallifron, who had access to official documents, only 8,000 Kromlides were recognized as Christians in 1859. 
eignty" ${ }^{56}$. Moreover, granting military exemption to the Kromlides could also be a dangerous precedent that would open the way for further Christianizations as a means to avoid military service.

Thus, the Kromlides were obliged to serve in the army as former Muslims and be recorded under both their Muslim and Christian names. In this way the Ottoman state ascribed officially to the Kromlides the double identity they had given up in favour of Christianity; furthermore the authorities placed them in a specially created hybrid category called the tenassur rum (literally: Christianized Orthodox), which referred to Greek-Orthodox Ottoman subjects sharing the Muslims' obligation to arms ${ }^{57}$. Ottoman tradition had similar precedents, such as the Christian sipahis of the fifteenth and sixteenth century ${ }^{58}$; nevertheless, this ad hoc solution was problematic at a time when modern state-building policy favoured the homogenizing of the subjects' obligations to the state rather than its opposite. The tenassur's obligation to arms was grossly contradictory to the conscription law of 1871 , the first article of which presented army service as an exclusively Muslim duty ${ }^{59}$.

Furthermore, in order to discourage further Christianization, the Ottomans submitted the Kromlides to various harassments ${ }^{60}$. On some occasions the latters' efforts to be exempt from military service (as Christians) without

56. Selim Deringil, “'There Is No Compulsion in Religion”,' p. 567.

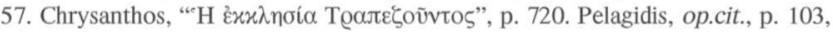
maintains on the basis of a report by the British consul Biliotti that the Kromlides were obliged to serve in the army first in the late 1860's. According to another report, this time by the British consul Palgrave, the Kromlides were not exempt from military service but managed to avoid it. Bryer, "The crypto-Christians", p. 66. According to other sources, the obligations of the Kromlides were regulated by an irade of the sultan Abdilmecid, according to which those liable for military service were only the actual converts not their descendants; after some time, however, the

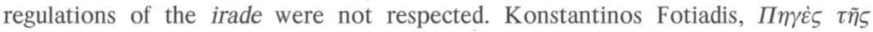

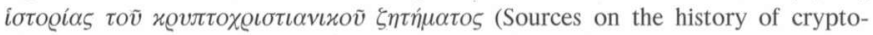
Christianity), Thessaloniki 1997, pp. 188-190. Although the issue cannot be properly dealt with without further research into Ottoman sources, we can safely assume that conscription was more or less a constant threat for the Kromlides.

58. See Halil Inalc1k, "Ottoman Methods of Conquest", Studia Islamica 2 (1954), pp. 112-122.

59. Erik-Jan Zürcher, "The Ottoman Conscription System”, pp. 446-447.

60. Compare Bryer, "The crypto-Christians", pp. 56-58. 
having to pay the exemption tax (as former Muslims) ${ }^{61}$ were turned ironically upside down: sometimes they were forced to serve in the army (as former Muslims) and simultaneously pay the exemption tax (as Christians) ${ }^{62}$. Moreover, the Ottomans eventually denied the converts property inheritance rights, on the basis that if a Christian could not inherit from a Muslim, neither could a Christian convert inherit from his Muslim parents ${ }^{63}$.

The Kromlides did their best to shake off their tenassur identity through the acquisition of Russian protection, the manipulation of documents ${ }^{64}$, or by migration. According to numerous accounts, at the end of the nineteenth century most men in Kromni and Santa had migrated to Russia on a permanent or seasonal basis ${ }^{65}$.

Another option was collective action. From the end of the century onwards, in petitions that the Kromlides sent to the Russian and Greek embassies in Istanbul, as well as to the Ottoman authorities, they modified their arguments and discourse carefully depending on whom they were applying to; they played the card of political loyalty with dexterity and showed a clear awareness of the potential of nationalism. Thus, when writing to the Greeks they stressed that they sought the protection of "mother Greece", to which they were bound by the "most sacred bonds of language

61. The Spathiotes in Albania did the same. Nikolaidou, op.cit., pp. 107-108.

62. Bryer, "The crypto-Christians", p. 66.

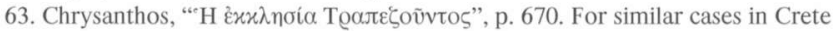
see Peponakis, op.cit., pp. 146-150.

64. According to one source, the community of Kromni manipulated the registers either by ascribing the children born into tenassur families to Christian families or by substituting the names and identities of deceased Christians with those of living tenassur, whose number were thus reduced to a minimum. "H Kow $\mathrm{H} \alpha$ "

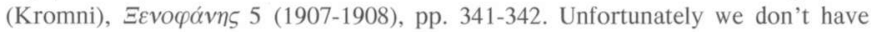
enough information about this operation; yet it certainly required not only the forbearance of the local authorities (which is hinted at in the source), but also a great deal of intra-communal cooperation, not least among the tenassur and the Christians, since a generalized strategy of this kind could lead to insurmountable complications concerning inheritance rights. A fruitful approach to this issue would require an analysis within the methodological framework of family history and historical anthropology.

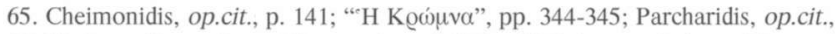
pp. 55-56. According to Ioannidis, op.cit., p. 247, by 1870 the population of Kromni had been reduced to the half of what it was before the failure of the mines. 
and religion" "66; they also stressed that by being secretly (en to krypto) Christians they had saved Greek nationality and Orthodoxy in the Pontic areas ${ }^{67}$. When applying to the Russians, the Kromlides offered allegiance to the protectors of the Orthodox subjects of the Sultan and underlined their cultural and political ties with the tsarist Empire, claiming that most of them "spoke and wrote the Russian language" ${ }^{6}$. Lastly, in their petitions to the Ottoman authorities of Trebizond the Kromlides pointed out that they would proudly perform their sacred military service, as befits every citizen (politis), if only all Christians were liable to it ${ }^{69}$; moreover, they attributed conveniently their forefathers' conversion to Islam to "unknown reasons" (while on other occasions they were ascribing it to cruel oppression) and argued that although the double identity of their ancestors was a deplorable fact, they, their descendants, should not be held answerable for it ${ }^{70}$.

The "crypto-Christian" question reached a second critical stage when the Ottomans attempted to strengthen the loyalty of the Empire's Muslim subjects in the late nineteenth century by promoting religious orthodoxy. Among the populations the Ottomans tried to relieve of religious error were the Stavriotes of the Akdağ region, a population of miners who were migrants from the Pontic region of Stavri and had not taken part in the action of 1857. Instead, the Stavriotes requested to be officially recognized as Christians only after the proclamation of the Ottoman Constitution of 1876, which reaffirmed religious freedom. Although their request was rejected, the free practice of their rites was tolerated and they were allowed to marry into the Orthodox community; furthermore, they refused to be registered as Muslims ${ }^{71}$. Nevertheless, from 1899 onwards they felt the

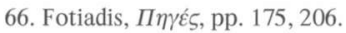

67. Ibid., p. 174.

68. Ibid., pp. 180-181, 183, 209, 220, 224. On other occasions, when addressing themselves to the Patriarchate or to the Greeks, the Kromlides presented migration to Russia as a national affliction. Ibid., pp. 250-251.

69. Ibid., p. 242. The Kromlides were rightly pointing out the contradiction inherent to their tenassur identity.

70. Ibid., pp. 241-243.

71. Deringil, The Well-Protected Domains, pp. 79, 207. The fact that the Stavriotes were not registered as Muslims was obviously an obstacle to the regular performance of their military service. However, at least some of them did not avoid carrying it out. I am grateful to Selim Deringil for this information. 
squeeze of the central state, which tried to make them abandon their heretical ways, to be recorded as Muslims, and to send their children to Ottoman schools. In 1905 Ottoman pressure culminated in the exile and eventual death of several community leaders ${ }^{72}$.

The Ottomans regarded the Stavriotes as a dangerous contamination that should not be allowed to spread $^{73}$. Consequently, they followed a much stricter course than they had done with the Kromlides. The field of negotiation between the Ottomans and their subjects had shrunk under the pressure of modern state-building policies that favoured nationalist attitudes with regard to identity and political loyalty. Selim Deringil has placed the Stavriotes correction project convincingly within the framework of the Ottomans' use of religious conformity as a vehicle for ideological reinforcement and legitimacy at the time of Abdilhamid II ${ }^{74}$.

The Ottomans were not alone in having taken this path. The appeals of the Stavriotes to Greece and to the Patriarch of Constantinople in 1906 show an elaboration of identity well embedded in nationalism:

"For three years we have suffered all kinds of afflictions for our religion and the race [genos] of our fathers. Nevertheless, neither our present nor our future misfortunes can daunt us, because our firm decision [...] is to sacrifice not only our fortune, but also our families and our very life" 75 .

"We do not tolerate being called Muslims anymore [...] whilst being in reality Christian Greeks" $"$.

After the Revolution of the Young Turks, national discourse became even more explicit. In 1909 the Kromlides addressed a petition to Georgios Bousios, member of the Ottoman parliament, stating that their forefathers

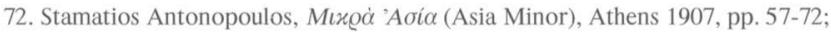
R. Janin, "Musulmans malgré eux ", pp. 495-505; Panaretos Topalidis, 'O Пóvtos

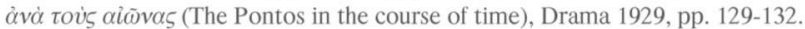

73. Deringil, The Well-Protected Domains, p. 79.

74. Ibid., pp. 78-81.

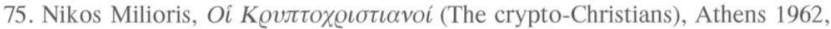
p. 31 .

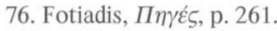


were "these Greeks who in the years of black slavery had retained in secret their national traditions and religious beliefs" 77 .

Soon afterwards the question was finally resolved. Since army service also became compulsory for non-Muslims, the principal raison d'être for the problem was eliminated. In 1910 the Kromlides and the Stavriotes were permitted to register solely with their Christian names ${ }^{78}$. Only a few years later, the hopes ignited by the Young Turk Revolution and the restoration of the constitution were extinguished by war and forced migration. The Ottoman authorities subjected the Stavriotes to new hardships; they refused to recognize them as Christians, they declared marriages between Christian men and Stavriotes women null and void, and tried to enlist the Stavriotes in Muslim army units ${ }^{79}$. Finally, the Kromlides and the Stavriotes were included in the exchange of populations between Greece and Turkey in 1922-1924 as members of the Orthodox Christian minority ${ }^{80}$. The choices of 1857 had come to a bitter end.

The foreigner's viewpoint: Kromlides and Stavriotes in the works of European travellers and scholars

According to Bryer, the earliest reference to the crypto-Christians of the Pontos seems to be by two American divines who passed through the Pontos in 1833. As he remarks, "crypto-Christianity naturally excited the interest of the numerous Western travellers and missionaries who crossed the Pontic Alps into Armenia" ${ }^{81}$. One of them was the Russian naturalist Tchihatcheff, who elaborated his first-hand experiences into a sentimental account focusing on personal drama and pangs of conscience ${ }^{82}$. Tchihatcheff was not only fascinated by the hybrid, exotic character of the Kromlides, this "abnormally

77. Ibid., p. 273.

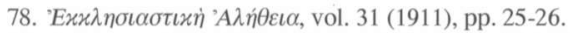

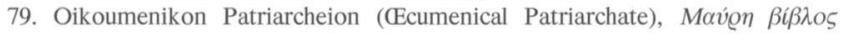

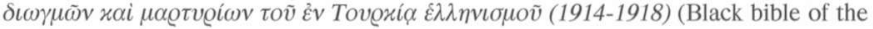
persecutions and martyrdoms of the Greeks in Turkey, 1914-1918), Istanbul 1919, pp. 285-288; Fotiadis, П†үદ́s, pp. 284-289.

80. Some of the Kromlides and the Stavriotes who either had not converted to Christianity or had re-embraced Islam stayed in Turkey as Muslims. Compare D. Papadopoulos, op.cit., p. 51.

81. Bryer, "The crypto-Christians", p. 31.

82. Tchihatcheff, Lettres, p. 20. It is interesting that the naturalist Tchihatcheff 
pseudo-Muslim population" " ${ }^{83}$; he also found that their adoration of Christianity was a proof of the "moral vitality of the Greek race" ${ }^{84}$. As we shall see, the Pontic Greek intellectuals of Tchihatcheff's time were less enthusiastic in regard to the Kromlides.

The Kromlides and the Stavriotes were mentioned by many European specialists on the geography, ethnography and history of Asia Minor, such as Vital Cuinet (who maintained that they were the descendants of Xenophon's Ten Thousand) ${ }^{85}$, H. Kiepert ${ }^{86}$, Edwin Pears ${ }^{87}$, R. Janin (a passionate advocate of the Stavriotes) ${ }^{88}$, and Karl Dieterich, a linguist and Byzantinologist who became Cavafy's first translator into German ${ }^{89}$. Depending on their political position, their attitudes varied from curiosity and haughty condescension to genuine sympathy, the latter gaining ground after the crisis of 1905. Until that time, Greek historiography and public discourse had dealt only marginally with the issue; but once Greek nationalism charged cryptoChristianity with a political message, it was in a position to capitalize on the accounts of the European specialists who had legitimized the Kromlides and Stavriotes as specific localities in their own right within the cultural-political cartography of Asia Minor.

However, two British anthropologists and archaeologists established the issue - as well as the term crypto-Christians - in scholarly literature. Frederick Hasluck published his article on the Pontic crypto-Christians in 1921, during the Greek Asia Minor campaign. Twelve years later, after the Greek defeat and the exchange of populations between Greece and Turkey had rendered obsolete any political currency that crypto-Christianity in the Pontos may have had, Richard Dawkins thoroughly re-examined the issue ${ }^{90}$. By that

also took a fancy to another "hybrid" social group, namely the Levantines of Istanbul. P. Tchihatcheff, Klein-Asien, Leipzig-Prag 1887, p. 177.

83. Tchihatcheff, Klein-Asien, p. 180.

84. Tchihatcheff, Lettres, p. 19.

85. Vital Cuinet, La Turquie d'Asie, vol. 1, Paris 1890, p. 12.

86. H. Kiepert, «Die griechische Sprache im pontischen Küstengebirge", Zeitschrift der Gesellschaft für Erdkunde in Berlin 25 (1890), p. 317.

87. Edwin Pears, Turkey and its People, London 1911, pp. 266-269.

88. Janin, "Musulmans malgré eux”, pp. 495-505.

89. Karl Dieterich, Das Griechentum Kleinasiens, Leipzig 1915, p. 13.

90. F. W. Hasluck, "The crypto-Christians of Trebizond", The Journal of Hellenic Studies 41:2 (1921), pp. 199-202. The article was later incorporated in Hasluck's post mortem publication that was edited by his wife Margaret: F. W. Hasluck, Christianity 
time crypto-Christianity in the Pontos belonged to a world that existed only in history and memory.

\section{Trebizond's viewpoint: The Kromlides in the works} of the first Pontic national intellectuals (1866-1870)

If conversion to Christianity was the way in which the Kromlides tried to adjust to the dilemmas of modernity, the Pontic-Greek intellectuals of the time were rather a product of that modernity. Situated in the most important urban settlement of Trebizond, these teachers, local historians and antiquaries after the middle of the nineteenth century began to collect data and publish books and articles about the Pontos' history and folklore, joining the efforts of the prestigious Greek Philological Association of Constantinople (Ellinikos Filologikos Syllogos Konstantinoupoleos) to build a national identity on the basis of education, language, folklore and history ${ }^{91}$.

This typically romantic endeavour implied the essentialization of the subjects of study, that is, their treatment as metaphysical qualities with an "inner" truth independent of their various ephemeral forms. The scholar had to establish a genealogy, to link the Greeks of his day to the glory of the

and Islam under the Sultans, vol. 2, Oxford 1929, pp. 469-474. R. Dawkins, "The crypto-Christians of Turkey", Byzantion 8 (1933), pp. 247-275. Both Hasluck and Dawkins were attached to the British School of Archaeology in Athens. As they were both interested in popular culture, they undertook travels together in Asia Minor, where they conducted extensive fieldwork and collected a significant amount of data that provided the basis for their studies. On Hasluck, Dawkins and the British School see the contributions in Shankland (ed.), Anthropology, Archaeology and Heritage, particularly David Shankland, "The Life and Times of F. W. Hasluck", vol. 1, pp. 15-67.

91. George A. Vassiadis, The Syllogos Movement of Constantinople and Ottoman Greek Education, Athens, Centre for Asia Minor Studies, 2007. See also Charis

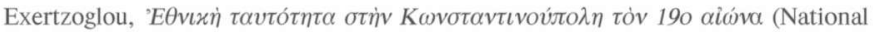
identity in Istanbul in the 19th century), Athens 1996. The pioneer work of llias

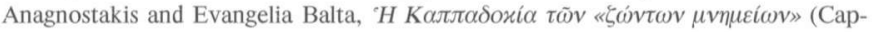
padocia of the "living monuments"), Athens 1990, about the linguistic, ethnographical and historical studies on Cappadocia by local Greek-Orthodox and Greek intellectuals of the 19th century has not yet found its counterpart in the Pontos. For a fruitful approach see Olga Sapkidi, "Collection of Pontic Folkloric and Linguistic Material", in Encyclopaedia of the Hellenic World, vol. 1: Asia Minor, http:/asiaminor.ehw.gr/ forms/filePage.aspx?lemmaId=10092 (accessed March 30, 2009). 
ancients $^{92}$. However, this attitude created a gap between an oligarchy of scholars and the "common people". The intellectuals of the Pontos did not fail to make clear that their bourgeois world was different in language ${ }^{93}$, mentality and socio-economic aspirations from the peasant world they often studied ${ }^{94}$. It is no wonder that crypto-Christianity did not figure as a key issue in their writings, although they were often published in Athens, where there was no fear of Ottoman censorship. These people had at their disposal a vast repertoire of arguments for the continuity of Hellenism in the region: a language that could be easily linked to ancient Greek, a rich folklore, and an educational network with the illustrious Frontistirion of Trebizond at the peak. Based on this, they argued for the continuity and vitality of a PonticGreek locality within the framework of the Greek nation.

Crypto-Christianity could blur this image. People with bad reputations and changing loyalties were not fit to function as symbols. Moreover, cryptoChristianity was not simply folklore. The researcher would be obliged to analyze the functioning of peasant societies that otherwise served mainly as providers of data, as unconscious bearers of a precious heritage ${ }^{95}$. The pioneer

92. On the attitude of the Greek-Orthodox "local" intellectuals of Asia Minor see

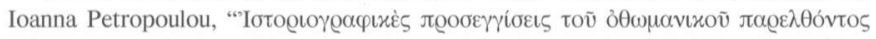

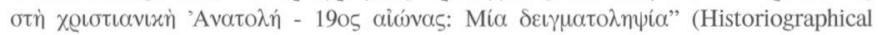
approaches of the Ottoman past in the Christian Orient - 19th century: a survey), $M v \dot{\eta}-$ $\mu \omega v 23$ (2001), p. 283.

93. The Pontic intellectuals naturally used the Greek Schriftsprache of the time, i.e. katharevousa, a "purified" version of Modern Greek, nearer in form and structure to ancient Greek.

94. The attitude of the Pontic scholars vis-à-vis popular culture was not only selective but often also moralistic and authoritative. In 1857, Georgios Papadopoulos, the local scholar and director of the school of Gümusshane held a violent attack against wedding customs that he considered as "barbarous, churlish, vain, debauched, idle and totally strange to the highest religion of Christ, to the holy and sacred mystery of marriage and to our self-sufficient and noble nation”. Georgios Kandilaptis,

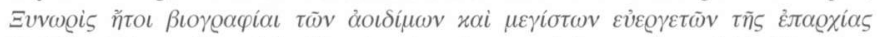
$X \alpha \lambda \delta i \alpha_{\varsigma}$ (Biographies of the illustrious benefactors of the province of Chaldia), Trebizond 1911, pp. 32-33. Papadopoulos was also the person who in 1846 translated the name of the town Gimisshane in Greek as Argyroupolis, a name that was adopted by the local Greek-Orthodox community. Ibid., p. 28.

95. The following extract from Triantafyllidis concerning the importance of Pontic folksongs illustrates perfectly his attitude towards popular culture: "Sometimes a churlish and brute lyra-player sings and makes merry with his like. We see him with 
among the Pontic intellectuals, Periklis Triantafyllidis, a native of Trebizond who had studied at the University of Athens and was the director of the Frontistirion, preferred to treat crypto-Christianity in an anecdotal way by narrating comical or moving stories that could move the educated reader to a condescending smile ${ }^{96}$.

Triantafyllidis was the first Pontic scholar to publish a book about the Pontic Greeks in 1866. There he touched also crypto-Christianity, referring in neutral terms to those "who recently declared themselves as Christians" 97. Triantafyllidis points out that the Kromlides' "true" identity was Christian, and it seems he had helped them in their effort to be recognized as such ${ }^{98}$. However, he did not regard them favourably. The hardiest and more perseverant Christians, he says, maintained their religion despite the Ottoman oppression, while others were Islamized. The klostoi constituted a third party that "tried to reconcile both: to ease conscience and to avoid oppression" 99 . After specifying (without any exaggeration) the approximate number of the klostoi, Triantafyllidis mentions some who did not join the others in declaring their "true" identity; he subsequently closes the presentation of the subject with a suggestion that could apply either to these last "hidden Christians" or to all klostoi:

contempt and irony, not knowing or not noticing whether this filthy ragamuffin has stored and expresses a precious report concerning our history". Triantafyllidis, $O i$ $\varphi v \gamma \alpha ́ \delta \varepsilon \varsigma$, p. 43.

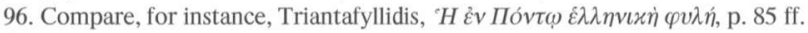

97. Ibid., p. 85.

98. Ibid., p. 94. Greek historiography had already dealt with the issue of "true" versus "false" identity with regard to the Kourmoulides of Crete, who in 1821 denounced Islam for Christianity and took part in the Greek War of Independence.

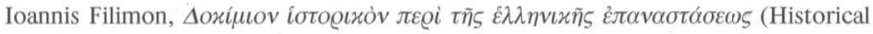
essay on the Greek revolution), vol. 4, Athens 1861, p. 395.

99. Ibid., p. 88. Compare the reserved - and indirectly negative - attitude of a Greek historian from Crete towards the crypto-Christians of the island: Vasileios

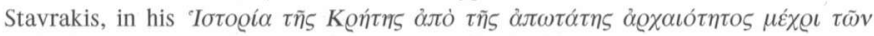
$\chi \alpha \theta^{\prime} \hat{\eta} \mu \tilde{\alpha} \varsigma \chi \varrho \delta \sigma \omega v$ (History of Crete from the farthest antiquity until our times), vol. 3, Chania 1909, p. 54, distinguishes sharply between the crypto-Christians (kryfoi), "whose number is not known, though surely not great", and the Christians proper who "stayed firm until the end to their fathers' religion and nation (en $t i$ patroa thriskeia kai ethnismo) despite all their various and horrible sufferings and afflictions". 
"And if their closer association with the Ottomans left a mark on them, they must wash it away with much effort and eagerness, must be purged through Greek education, and prove themselves worthy of this sympathy [i.e. of the sympathy of their Greek compatriots]. It is also suitable and necessary to establish a common holiday, perpetuating this great national achievement" ${ }^{100}$.

Triantafyllidis' obsession with purity in its literal and metaphorical sense (body, clothes, manners, language, culture, identity), which is evident in his book, led him see in crypto-Christianity a stain, a sin that should be washed off the national body. The purification of the sinners should be achieved through national education: under the guidance of Triantafyllidis' and his like the estranged klostoi would return to the bosom of the nation. But this was not enough. A national holiday was recommended as well, a ritual that would enforce ideological cohesion and establish a shared memory for the national community. Triantafyllidis' role in this process was to be that of an instructor and a master of ceremonies: the last hundred pages of his book contain speeches he had delivered on school holidays ${ }^{101}$.

Some years later, in 1870, Triantafyllidis returned to the Kromlides and made the first attempt to date the incipience of crypto-Christianity in the Pontos, placing it in the fifteenth century. His attitude towards the Kromlides remained ambivalent and he did not hesitate to present them in a negative light, probably reproducing social biases: thus, he equates secretiveness with hypocrisy when he claims that the Kromlides, "due to their hypocrisy in religious matters, got used to lying, and the tendency to lie is a characteristic of the natives" ${ }^{102}$.

In the same year, Savvas Ioannidis, a native of Demirdesi (Turkish: Demirdaş) near Bursa who, like Triantafyllidis, had studied at the University of Athens, offered in his History and Statistics of Trebizond, possibly the

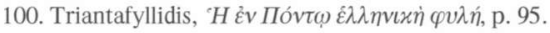

101. Ibid., p. 203-299. About the religious and national holidays of the Ottoman

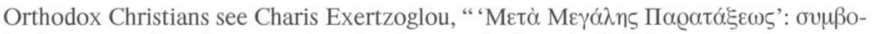

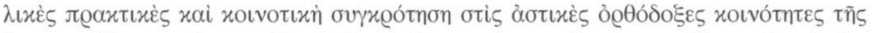

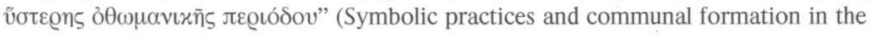

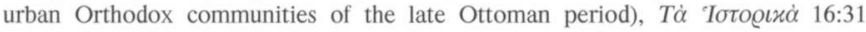
(December 1999), pp. 349-380.

102. Triantafyllidis, Oi $\varphi v \gamma \alpha ́ \delta \varepsilon \varsigma$, p. 103. 
most influential book about Greeks in the Pontos ${ }^{103}$, a more sympathetic view of the Kromlides. His description of the Kromlides' past illustrates well a national intellectual's difficulty in accepting the "blurred" socio-cultural conditions of the Kromlides' situation:

"It is strange how they managed this situation for so long, being actually Christians and doing everything in a Christian way without being revealed to the other Muslims, although known by the Christians" 104 .

Ioannidis also stressed the Kromlides' struggle to be recognized as Christians and presented a short but precise account of the developments between their declaration and their official recognition. Crypto-Christianity, however, did not carry in his work any particular symbolic function and remained more or less a marginal issue ${ }^{105}$.

Ioannidis' aim, like that of Triantafyllidis before him, was to put Pontic Greeks on the Greek national map. By making them known to a wider public, by applying in the analysis the national hermeneutics of folklore, linguistics, and history, they both wanted to prove that, as Triantafyllidis put it, citing Arrian, "there is also in the Pontos a city called Athens and a Greek

103. After teaching at Greek schools in Plovdiv (Greek: Filippoupolis) and Giresun (Greek: Kerasounta), Ioannidis came in Trebizond, where he taught at the

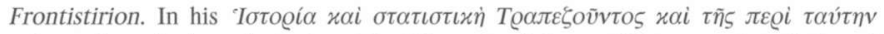

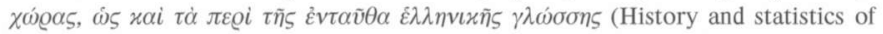
Trebizond and the surrounding areas, including the Greek language spoken in the region), Istanbul 1870, he published folklore data he had collected during extensive field studies. Among Ioannidis' achievements is the discovery of the MS of the Byzantine Epic of Digenis Akritas, which was published by Sathas and Legrand, and

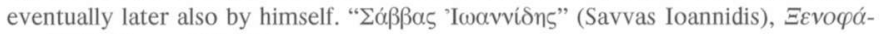
vnऽ 7 (1910), pp. 382-388.

104. Ioannidis, op.cit., p. 145.

105. Ioannidis' account on crypto-Christianity was faithfully copied by Tryfon

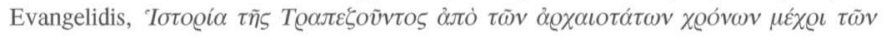
$\varkappa \alpha \theta^{\prime} \dot{\eta} \mu \tilde{\alpha} \zeta$ (History of Trebizond from ancient times until today), Odessa 1898, pp.

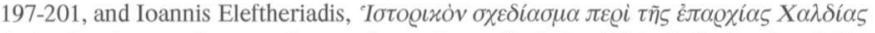

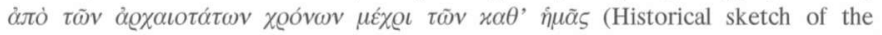
province of Chaldia from ancient times until today), Athens 1903, pp. 55-56. These scholars did not add anything new to the issue. 
sanctuary" ${ }^{106}$. Their crucial argument was continuity: Ioannidis claimed that no European city, not even Rome, could boast of Trebizond's long national, linguistic and cultural continuity, and that in no other Greek land were the ancient Greek place-names preserved to the degree they were in the region of Trebizond ${ }^{107}$.

The rather disreputable crypto-Christians did not fit in with Triantafyllidis' and Ioannidis' emphasis on purity, continuity, and constancy. Exactly as they glorified endurance, both savants detested ambiguity. Both spoke vehemently against the widespread migration of Pontic Christians to Russian territory, a process that they feared would result in the migrants' loss of their mother tongue and in their "conversion" to another nation ${ }^{108}$.

Triantafyllidis' and Ioannidis' main concern was education, a national struggle that must be won at all costs. Crypto-Christianity was a small episode in the nation-bulding process, and they both hastened to declare it finished: as Ioannidis put it, the Kromlides "follow their religion without obstacles, being only subject to military service", and "enjoy a perfect peace" ${ }^{109}$.

Almost nothing was added to the works of Triantafyllidis and Ioannidis concerning the Kromlides for the next thirty-five years. Indeed, their pioneer work on Pontic Greeks was continued only after another generation of Pontic intellectuals began to publish towards the end of the century. Among the very few publications that appeared in the meantime was the small study of Avraam Papadopoulos on the region of Sourmena (Turkish: Sürmene) in the eastern Pontos. Papadopoulos referred to crypto-Christianity in a strikingly distant way. In the small paragraph he devoted to the issue, he gave the exact number (a very small one) of the klostoi in three of the region's villages and, as if he wanted to clear his homeland of any suspicions, hastened to affirm that there were no more klostoi in the other villages ${ }^{110}$.

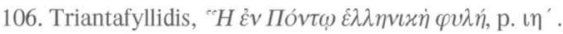

107. Ioannidis, op.cit., pp. 156, 180.

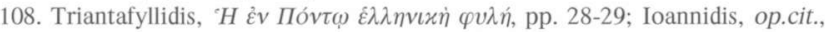
p. 166.

109. Ibid., pp. 134, 212.

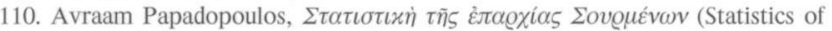
the province of Sourmaina), Athens ${ }^{2} 1938$ (first edition: Athens 1882), p. 36. 
The viewpoint of the Mikrasiates of Athens (1896-1910)

In 1897 Epameinondas Kyriakidis, another teacher at the Frontistirion of Trebizond, published in Athens a book containing biographies of Pontic Greek scholars from the Ottoman conquest until his own day. There he referred very briefly - and somewhat cryptically - to "those who could not practice their religion openly, being obliged to worship Christ in secret" "II. Kyriakidis repeated almost verbatim these words one year later in his book about the Panagia Soumela monastery ${ }^{112}$. It is indicative that in both cases he mentioned en passant the Kromlides in passages dealing with the Pontic monasteries and their contribution to the preservation of Christianity, Greekness and Greek education in the Pontos.

Like Triantafyllidis and Ioannidis, Kyriakidis focused on education and the continuity of the nation. Unlike them, he neither dealt with folklore nor composed "general" studies. His works, full of footnotes and citations, were carefully focused on particular issues, for instance the Pontic scholars, the Panagia Soumela monastery, or the Frontistirion. Kyriakidis belonged to a second generation of Pontic Greek intellectuals who had studied in European universities and were more "professional" and methodologically informed than their teachers. Not surprisingly, some of them settled down in Greece. Kyriakidis himself was one of the leading figures among the Asia Minor Greeks (Mikrasiates) of Athens who had founded the club Anatoli (Orient) in 1891 and published the journal Xenofanis from 1896 until 1910.

Since its foundation, the club Anatoli had been particularly active in the field of education. Several Greeks from Asia Minor were given scholarships in order to study in Athens and then return to their native lands as teachers and propagators of national ideals. The club functioned as a counterbalance to the Greek Philological Association of Constantinople, which had been sponsoring education and literature among the Orthodox subjects of the Porte since 1861 . Backed by important representatives of Greek public life, Anatoli aimed at the formation of an imagined community of Asia Minor

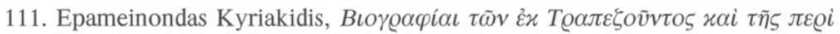

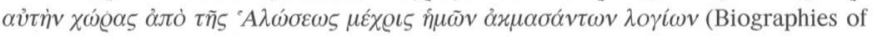
scholars from Trebizond and the surrounding areas from the time of the Ottoman conquest until today), Athens 1985 (reprint of the first edition, Athens 1897), p. 57.

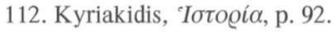


Greeks within the framework of the Greek nation and under the auspices of Athens rather than Constantinople ${ }^{113}$.

The objectives of Xenofanis, the club's journal, were in the editors' words "the historical and factual study of Asia Minor" ${ }^{14}$. Its articles - apart from those that dealt with history, geography, ethnography, and archaeology - focused on current issues. The most important among them were Greek education, the effort to establish the Greek language among the Turkish-speaking Orthodox, and the struggle against the activities of Protestant missionaries. But the journal did not function solely as a reliable source on Asia Minor. More than that, Xenofanis was the stage on which the educated Asia Minor elites were to represent themselves and their respective homelands in front of their compatriots and under the formative guidance of their leaders, the Athens-based Mikrasiates of Anatoli. Xenofanis was creating an image of Asia Minor Greeks, in which the educated elites of the region could recognize themselves as part of a wider community ${ }^{115}$. Not only were the articles' authors mostly local teachers and antiquaries; but the Orthodox of Asia Minor also constituted the main readership of the journal.

Xenofanis remained almost totally silent in relation to crypto-Christianity. Thus, in 1896 the author of a small article about Santa omitted altogether the Kromlides and wrote somewhat emphatically that the inhabitants "perform their religious duties faithfully and devoutly" "16. Similarly,

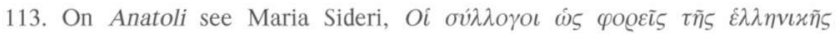

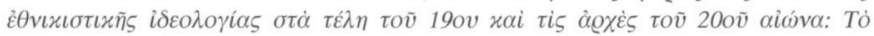

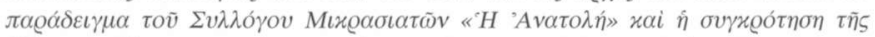

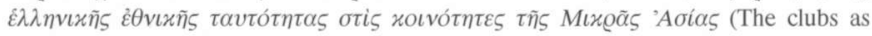
carriers of Greek nationalism at the end of the 19th and the beginning of the 20th century. The example of the club "Anatoli" and the formation of Greek national identity in the communities of Asia Minor), unpublished Ph.D. Thesis, University of the Aegean, Mytilini 2003.

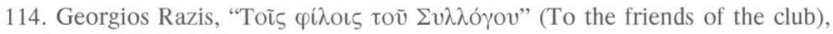

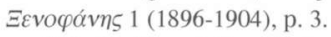

115. On the relationship between printed word and the formation of imagined communities see above all Benedict Anderson, Imagined Communities. Reflections on the Origin and Spread of Nationalism, London ${ }^{2} 1991$.

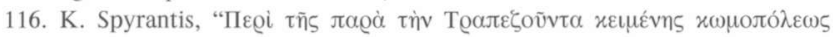

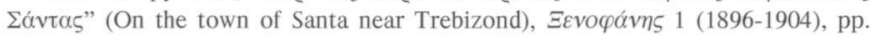
446-453. 
no mention of the Kromlides appeared in a 1905 presentation of the village Poulantzaki ${ }^{117}$, while the anonymous author of an article about the Pontic region of Chaldia ignored the Kromlides but identified Akdağ Maden as the place where "the question of the klostoi, the Christian migrants from Stavri, was raised" "118. It is obvious that the author did not want to elaborate on the subject; he confined himself to a neutral remark that was comprehensible only by those already familiar with the issue. Lastly, the anonymous author of an article about Kromni mentioned the "secret followers of Orthodoxy" adding that "as is known, most Greeks in our region were formerly Islamized" "19. This was all he had to say about the Kromlides' multiple conversions; yet he elaborated on the tricks by which the inhabitants of Kromni had supposedly managed to get rid of their Muslim names and thus avoid military conscription. According to him, if the other villages of the region had followed this example, migration to Russia, this "infliction put upon the nation", would have ceased ${ }^{120}$. The author's priority was to propose a strategy on an important national issue, not to speak about Kromni's dubious past.

The scarcity of allusions to crypto-Christianity in Xenofanis is not hard to explain per se. Apart from certain subjects from ancient and early Christian history that had clearly a symbolic function, the journal focused on the present and the future rather than on the past and, exactly like the anonymous writer from Kromni, proposed solutions for the great national issues of language, education, and religion. If Xenofanis's silence is intriguing, it is because the Ottoman correction project with regard to the Stavriotes took place during the journal's time of publication. Their appeal to Greece in 1905 did not pass unnoticed. Contrary to the silence kept by the journal, the club Anatoli took part in the effort to help the Stavriotes by appealing on their behalf to foreign embassies and the Greek government ${ }^{121}$. When, in 1907, the former Greek consul of Smyrna Stamatios Antonopoulos devoted

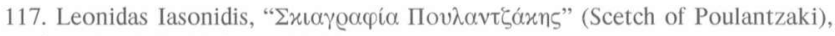

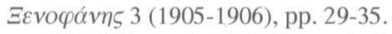

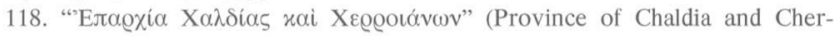

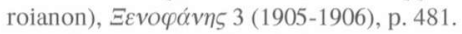

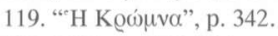

120. Ibid., pp. 343-344.

121. Sideri, op.cit., p. 212 , footnote 360 . The Kromlides had already sought the club's help in 1904. Fotiadis, П¥үદ́s, pp. 251-254. 
a whole chapter to the Stavriotes in his important study on Asia Minor ${ }^{122}$, Epameinondas Kyriakidis, the reviewer of Antonopoulos' book in Xenofanis, rightly pointed to the author's mistakes concerning the etymology of the name Stavriotes, and added that he, Kyriakidis, had met the secret Christians (kryfious christianous) in Stavri long before their existence became widely known ${ }^{123}$. Kyriakidis' criticism, however, only made Xenofanis' silence louder.

One would assume that the journal's editors refrained from dealing with a delicate issue that could provoke an Ottoman reaction against the journal's free circulation in Asia Minor. The journal, however, had often housed articles that were openly anti-Ottoman, without any concern about future reaction. The reason for Xenofanis' silence was in all probability that crypto-Christianity was not considered to be carrying a particular message for the literate Greek elites of Asia Minor. First, the ambiguity of crypto-Christianity could blur the Mikrasiates' aspiration to national purity; secondly, crypto-Christianity, contrary to the Turkish-speaking Orthodox, another "hybrid" - and therefore also problematic- issue, was geographically and numerically limited.

In his 1903 travelogue of the Pontos, the Greek politician Konstantinos Papamichalopoulos followed the line of Anatoli and Xenofanis. Although he passed through the settlements of the Kromlides, he did not devote more than two short paragraphs to crypto-Christianity; the first while emphasizing the monasteries' contribution to the maintenance of Orthodoxy ${ }^{124}$, and the second when he referred vaguely to a people who, as he wrote, had been - and

122. Antonopoulos, op.cit., pp. 57-72.

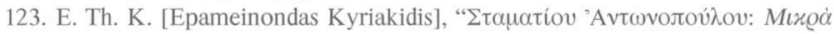

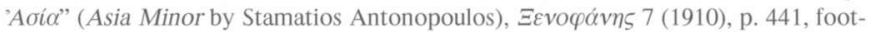
note 1. Kyriakidis' critical position towards Antonopoulos probably had other motives as well. We can safely assume that the milieu of Anatoli did not receive well the remarks of Antonopoulos (op.cit., p. 18) on the lack of national feelings among the Orthodox of Asia Minor, who kept identifying themselves as Romaioi (Rum) rather than Greeks. Moreover, the introduction of the book contained also an article

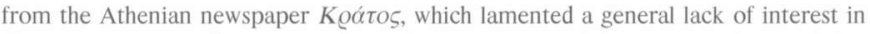
Greece concerning the Greeks of Asia Minor. It praised the activity of Anatoli but considered the club unable to promote the cause of Asia Minor Greeks, due to its being poorly supported and to its keeping a low profile. Ibid., p. 4.

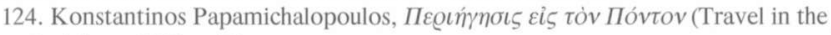
Pontos), Athens 1903, p. 74. 
partly still were - Muslims in the open and Christians in secret (en to krypto Christianoi) ${ }^{125}$. The writer's main interests - apart from economic facts, of which he gave numerous tables - were typical for the national imagining of the Pontos: history (above all Xenophon's Ten Thousand and the Empire of Trebizond), monasteries, Pontic Greek as an archaic Greek dialect, the thriving Greek communities and their schools, and the danger of missionary activity. The labours of the Pontic intellectuals and Anatoli had not been in vain.

\section{The model Greek consul and the Patriarchate (1905-1911)}

Crypto-Christianity in the Pontos remained factually unknown in Greece for a long time; the Black Sea coast was still far from the hopes and fears of Greek irredentism. Only Greek diplomats regarded crypto-Christianity as a "national and sacred cause" in their reports from the 1850's ${ }^{126}$. However, the recognition of the Kromlides put the issue at rest. Things only changed towards the end of the century, partly due to the offensive policy of the Ottomans towards the Stavriotes, who in their turn sought help from foreign embassies and from the Greek state in 1905. Greek newspapers reported the issue, a demonstration was organized, with Pavlos Karolidis, a professor of History at the University and Mikrasiatis by descent, as the main speaker, and a resolution was delivered to the European embassies ${ }^{127}$.

Two years later, Stamatios Antonopoulos first introduced crypto-Christianity to the Greek public as an actual political issue. Echoing his colleagues who had served at the consulate of Trebizond fifty years earlier, he argued that the question of the Stavriotes, those "martyrs" who declared that "they preferred death than Islamization" ${ }^{228}$, was in fact a major national cause, and blamed the Greek state for its lack of interest and the Patriarchate of Constantinople for having failed to rise to the occasion. Antonopoulos presented the Stavriotes in a heroic light that dissolved ex posteriori all shadows of ambiguity. His choice of words was not accidental; for Antonopoulos the declaration of the Stavriotes' "true" identity and their struggle for recognition put them in the position of those neo-martyrs during Ottoman rule who returned to Christianity after having converted to Islam. According to their

125. Ibid., p. 148.

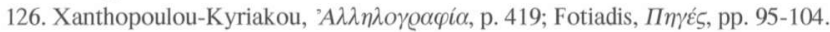

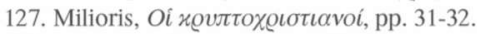

128. Antonopoulos, op.cit., pp. 71, 64. 
vitae, the open denial of Islam and the subsequent death penalty absolved them from the crime of apostasy. In his reading of the Stavriotes' situation, Antonopoulos implemented a national interpretation of martyrdom that had been already elaborated in Greek national discourse ${ }^{129}$.

Antonopoulos, a member of the Greek diplomatic corps, argued for an offensive national policy in Asia Minor that would be led by the Greek state and would overshadow the activity of any intermediary or eventual competitor, such as the Mikrasiates of Anatoli or the Patriarchate of Constantinople. Athens, the national centre, should establish strong direct links with the Greek Orthodox, secure for itself their political loyalty, and underline its claims upon them, mainly through its consular network ${ }^{130}$. It is no accident that the historian Pavlos Karolidis, in the prologue he wrote for Antonopoulos' book, used for Asia Minor the term Asiatic Greece (Asiatiki Ellas) and regarded Antonopoulos as a model Greek consul ${ }^{131}$.

Two years later, in the euphoria that followed the Young Turks' coming to power, the Patriarchate, answering Antonopoulos' accusations indirectly, published a booklet containing the relevant documents and memoranda it had addressed to the Porte over the last few years ${ }^{132}$. The national aspect of crypto-Christianity was, of course, lacking from the documents, which dealt not only with the Stavriotes but also with Islamization. This was totally in accordance with the Patriarchate's stressing in the booklet its own intermediary role in the integration of the Orthodox subjects of the Empire and with its arguing for a regularization of their position within the Ottoman state according to the newly resurrected constitution. Indeed, the Patriarchate indirectly put the blame for the oppression of the Stavriotes on the absolutism of Abdilhamid's rule, and hinted that the course the new government

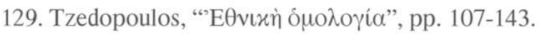

130. On Greek national politics in relation to the Orthodox of Asia Minor see Sia

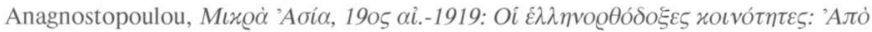

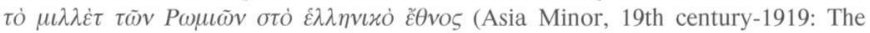
Greek-Orthodox communities: From rum millet to the Greek nation), Athens 1997, pp. 419-452. On the Greek consular network in Asia Minor see pp. 438-444.

131. Antonopoulos, op.cit., pp. $\xi^{\prime},\left\llcorner\gamma^{\prime}\right.$.

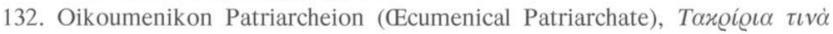

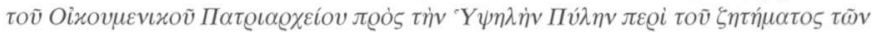

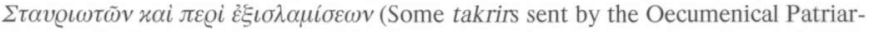
chate to the Porte on the issue of the Stavriotes and on Islamization), Istanbul 1909. 
would take on this issue would be an indicator of its sincerity concerning constitutional rights ${ }^{133}$.

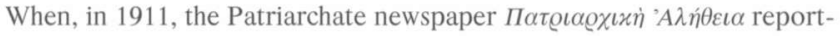
ed on the solving of the question of the Kromlides and Stavriotes, the discourse was strikingly different, as the Patriarchate was no longer addressing the Porte but the wider public of Greek-Orthodox subjects of the Empire. Manouil Gedeon, the newspaper's editor, propagated an interpretation of crypto-Christianity that was compatible to the Patriarchate's quest for legitimacy within a reformed and constitutional, multiethnic and multiconfessional Empire. This interpretation did not ignore national discourse; yet, by placing it within the framework of the Orthodox Church and, above all, by stressing continuity rather than rupture, it weakened its edge.

According to the article, crypto-Christianity was not confined to the regions of Kromni and Akdağ, but was widespread in many parts of the Ottoman Empire; all crypto-Christians were urged to come forth and proclaim their true identity. Moreover, crypto-Christianity was considered not simply a result of oppression and persecution but a divine plan for the maintenance of nationality and religion. Thus, Gedeon formed from the Stavriotes' and Kromlides' example the basis of a crypto-Christian narrative that washed away the stain of Islamization by laying emphasis on the hidden continuity of nation and religion. The ambiguous crypto-Christians of the past were now those "who had for centuries saved Christian faith in subterranean churches and catacombs" ${ }^{134}$. In this interpretation it was crucial that the interest in crypto-Christianity be transferred from the moment of confession to the previous period of secret worship, from rupture to continuity ${ }^{135}$. Yet this was not the first whole-heartedly positive evaluation of crypto-Christianity in the Pontos.

133. Ibid., pp. 3-4.

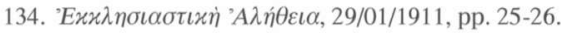

135. Gedeon stressed further the aspect of continuity in crypto-Christianity in his

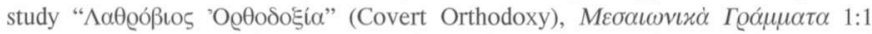
(1930), pp. 79-95. At the same time he condemned martyrdom as inhuman and fanatical. For an analysis of Gedeon's ideological assumptions on the subject see

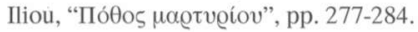


The insider's viewpoint: Local histories, local politics in Santa and Kromni (1902-1912)

In 1902, Filippos Cheimonidis ${ }^{136}$, a young man from Santa, published in Athens an extraordinary book under the title History and Statistics of Santa. Given the status of Savvas Ioannidis' 1866 study on the Pontos, it would be impossible to miss the fact that Cheimonidis had imitated its title and provocatively substituted Santa for the Pontos. Indeed, Cheimonidis' aim was to do for Santa what Triantafyllidis and Ioannidis had done for the Pontos, namely to put it on the national map. As other sources were lacking, the author followed a course unique among Pontic Greek historians: he based his research mainly on archaeological evidence, oral tradition, and Ottoman documents. Some of the latter appear to have been genuine but others seem falsified or fabricated. Cheimonidis was not responsible for the falsifications; they were most probably done in former times by community leaders who wanted to ensure Santa's rights over contested summer pastures ${ }^{137}$. Furthermore, a ferman ensuring the privileged status of Santa, which probably functioned as a "founding myth" of the community, seems to have been completely non-existent ${ }^{138}$.

Yet, according to Cheimonidis' account, neither the particular ferman, nor the fact that Santa was already enjoying the privileges of a mining centre through being attached to the mines of Gümusşhane, were enough to protect the community from its Muslim neighbours' aggression, which was partly due to contested summer pastures. It was at this point, the author says, that a significant number of the population "pretended conversion" to Islam and by this device "saved the homeland (patrida) in terrible circumstances" ${ }^{139}$. Contrary to the somewhat impressionistically described oppression of the Christians, Cheimonidis' suggestions concerning Islamization are

136. At that time Cheimonidis, who was later to take his place among the teachers of the Frontistirion of Trebizond, was 25 years old and, according to Papamichalopoulos, who knew him, was studying medicine at the University of Athens. Papamichalopoulos, op.cit., p. 140.

137. I am thankful to Eleni Gara for this suggestion.

138. The particular ferman was supposed to be a result of the inhabitants' mining skills and to grant the community of Santa an autonomous, privileged position. Cheimonidis, op.cit., p. 41.

139. Ibid., pp. 56-61. 
of analytical value, as they refer to precise socio-economic realities. Yet this does not mean that they are ideologically neutral. Cheimonidis emphatically challenged the ambivalent attitudes towards the klostoi by declaring:

\begin{abstract}
"we repeat once more that they [the klostoi] are worthy of our gratitude, because the maintenance of religion and the integrity of our country are due for the most part to their influence. They were the fiercest adversaries of Santa's enemies and its warmest supporters. This is obvious even to those who have but lightly tasted the history of our homeland and it is needless to prove it further" ${ }^{140}$.
\end{abstract}

Indeed, a great part of Cheimonidis' account was devoted to the struggles of the inhabitants of Santa against the neighbouring ağas, struggles that were mostly led by the klostoi and often took the form of armed combat ${ }^{141}$. Cheimonidis interwove crypto-Christianity with armed resistance and presented them as the foundation of Santa's continuity.

Cheimonidis was cautious to interpret crypto-Christianity as a communal decision, a collective strategy. It was the community that decided who was to "pretend" conversion to Islam and sought efficient measures to ensure that the converts would not be estranged from Christianity. Thus, every allusion to the klostoi's dubious morality became totally unfounded. Moreover, the emphasis on the villagers' ability to take collectively effective measures constituted them as an autonomous political body, a nation within the nation, a Pontos within the Pontos.

Cheimonidis presented Santa as an entity in itself, an enclosed locality with a minimal dependence on the world outside. Trebizond is strikingly absent from his account; as for the monasteries, he did not refrain from accusing them of bribing the Patriarchate in order to avoid the foundation of a new diocese in the territories under their jurisdiction ${ }^{142}$. Santa, according to Cheimonidis, owed gratitude to neither monks nor scholars. On the contrary, it was the other Pontic Greeks who should be grateful to Santa, since the valour and cleverness of its inhabitants had made it a resort for the

140. Ibid., p. 117, footnote 1.

141. Ibid., p. $75 \mathrm{ff}$.

142. Ibid., p. 127. On the new diocese of Rodopolis see also Kyriakidis,

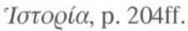


oppressed Christians of the Pontos ${ }^{143}$. In this context any discussion of the klostoi's multiple identities would be out of place. They were Santaioi; that was enough.

Ten years later, Cheimonidis' book was followed by a history of Kromni published in Trebizond by A. Parcharidis, a scholar belonging to the literate elite of the town ${ }^{144}$. Although the writer did not share Cheimonidis' radical attitude, his main points followed more or less the same course. As his predecessor had done for Santa, Parcharidis projected Kromni's foundation back to the time following the capture of Trebizond. He also referred to privileges established by dubious -and by his time lost-imperial fermans, as that of Murad IV that supposedly granted Kromni absolute rights over the nearby summer pastures ${ }^{145}$. Contrary to Cheimonidis, he did not ascribe crypto-Christianity to a communal strategy but to the persecution of the Christians. However, his evaluation of crypto-Christianity was just as eloquent and perhaps more assertive: at a time, he said, when children of emperors, archbishops and wise magnates turned to Islam and became the fiercest persecutors of the Christians,

"these few illiterate and coarse mountaineers mocked a religion and by this means became the protectors of their Christian brethren" ${ }^{146}$.

Kromni is here juxtaposed to Trebizond, and the comparison is unfavourable to the latter. In the wise magnate we should probably recognize Georgios Amiroutzis, a scholar and high official of the Empire of Trebizond, whose eventual conversion to Islam after the fall of Trebizond was an embarrassment to national historians of the Pontos, such as Kyriakidis ${ }^{147}$. Crypto-Christianity, on the contrary, was not really apostasy but the adoption of a false identity ${ }^{148}$.

143. Cheimonidis, op.cit., p. 52.

144. Parcharidis, op.cit. His father, Ioannis Parcharidis, was another Pontic Greek scholar who had studied at the University of Athens and had later taught at the Frontistirion. He was also the author of a grammar of the Pontic dialect and the editor of the journal 'A

145. Ibid., pp. 42-43.

146. Ibid., p. 43.

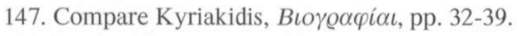

148. Parcharidis, op.cit., p. 38. 
Parcharidis evaluated crypto-Christianity exactly as Cheimonidis had done. For him, far from being a moral stain, this was the vehicle that made the continuity of nation and religion possible, not only in Kromni but also in the wider region. The Islamized Kromlides, by securing for themselves the positions of superintendents of mines, managed to invest Kromni with a privileged status; thus, wrote Parcharidis, Kromni attracted many Christians who were persecuted by derebeys in other regions ${ }^{149}$.

Moreover, even if Parcharidis did not interpret Islamization in precisely the same terms as had Cheimonidis, he linked it not only with survival tactics but also with social relations and power. The elite of the Islamized Kromlides, he maintained, although they protected Christianity, were no different in status and attitude to the other derebeys of the Pontos, being cruel, oppressive and rapacious ${ }^{150}$. Reading between the lines, Parcharidis lets us glimpse Islamization in terms of social inequality and power relations.

This perception of Islamization is in accordance with Parcharidis' persuasive interpretation of the 1857 proclamation of the Kromlides" "true" identity. In his dry, matter-of-fact formulation, their profession of Christianity is totally deprived of any sentimentality, being presented as a choice based on socio-economic considerations. This rather distant attitude of Parcharidis was also due to his book being published in 1912, after the Young Turks had come to power. The question of the tenassur had been solved a year ago. Crypto-Christianity was a last remnant of the times of oppression and absolutist rule, for which Cheimonidis used the standard Greek historiographical term Tourkokratia ${ }^{151}$. What was now crucial for Kromni was to adapt to the new circumstances. Parcharidis was optimistic: Kromni had its own schools, managed by its own educational club based in Trebizond; a new generation was being brought up "according to the standards of new civilization"; a new road had been constructed at the expense of the community; an agricultural club had been recently established ${ }^{152}$. Lastly, Kromni had the potential to become a perfect summer resort for the bourgeoisie of Trebizond ${ }^{153}$. The Kromlides' multiple identities belonged to the past.

149. Ibid., p. 39.

150. Ibid., pp. 67-69.

151. Ibid., pp. $58,71$.

152. Ibid., pp. $56,57$.

153. Ibid., pp. $22,57$. 
Cheimonidis and Parcharidis did not invent their own interpretations of crypto-Christianity. Both "translated" into historiographical terms views and attitudes that must have been current in Santa and Kromni. For local societies conversion was not the unintelligible, morally dubious occurrence it had been for the intellectuals of Trebizond; but a choice based on social and economic considerations that were embedded in the dynamics of communal life and which worked both ways, from Christianity to Islam and vice-versa. Given the pre-eminence of the former Kromlides in local politics, the emergence of a narrative that presented them in a favourable light is not surprising. When the new educated elites of Santa and Kromni, who were more or less products of the educational network of Trebizond, claimed a special place on the national map for their homelands, they treated crypto-Christianity as the factor that invested Santa and Kromni with a historical mission within the Pontos: the ignorant, vulgar peasants whom Triantafyllidis had despised had saved the nation.

\section{Athens' viewpoint: Crypto-Christianity and the Asia Minor Campaign} (1918-1922)

Parcharidis' optimistic dreams about Kromni were short-lived. The Balkan Wars of 1912-1913 and the First World War found Greece and the Ottoman Empire in opposite camps, with catastrophic results for the Orthodox of Asia Minor. The end of the war put the solution of the Eastern Question onto the international agenda. Just before and during the Greek army Asia Minor campaign of 1919-1922, a plethora of historical, geographical and ethnographical works about Asia Minor was published to legitimize Greek territorial claims. In this process Asia Minor, according to Karolidis' expectations, became the "Asiatic Greece", an ideological locality directly dependent on Athens, the Greek national centre. In many of the works published at this time, crypto-Christianity served to prove that most Muslims in Asia Minor were originally Islamized Greeks, and to hint at the possibility that many contemporary Muslims were in fact crypto-Christians ${ }^{154}$.

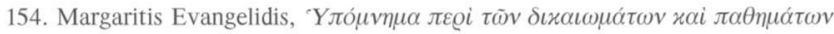

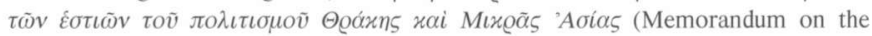
rights and sufferings of the hearths of civilization in Thrace and Asia Minor), Athens

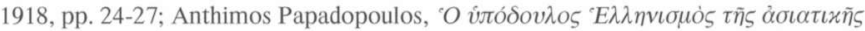

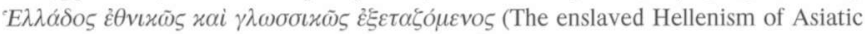


The Mikrasiates of Anatoli played a leading part in providing legitimacy for Greece's national ambitions through the instrumentalization of cryptoChristianity. In fact, the club complied with the aggressive nationalism of the time, only too understandable in the circumstances of a Greek expedition in Asia Minor. Margaritis Evangelidis, the president of the club, was also president of the Committee of Unredeemed Greeks ("Koini ton alytroton Ellinon epitropeia"), which was established in 1917 in order to propagate Greek national demands in Asia Minor and Thrace. Similarly, Konstantinos Lameras, the club's vice-president, was the secretary general of the committee. Both felt free to advertise crypto-Christianity in a way they had not

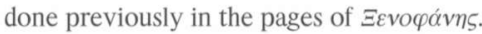

It was Lameras who made the decisive step in the transformation of crypto-Christianity by placing the Kromlides, the Stavriotes, the Yiiriiks, the Kızılbas, and other "non-Turkish" elements of Asia Minor into a larger group, the "Turkish-appearing Greeks" (Ellines tourkophaneis) ${ }^{155}$. Thus, Lameras passed from the "Christians in secret" (en to krypto Christianoi), to the "Greeks in secret" (en to krypto Ellines), who retained "in different extent the knowledge of their Greekness, without daring to proclaim it" ${ }^{156}$. It is interesting that in his exercises of political arithmetics the Kromlides and the Stavriotes did not account for more than $6.7 \%$ of his total number of "crypto-Greeks" ${ }^{157}$. Their usefulness did not lay in their numbers; nor in the precise circumstances of their situation.

Greece examined in linguistic and national terms), Athens 1919, pp. 39-50; Notis

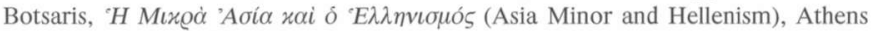

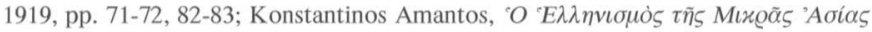

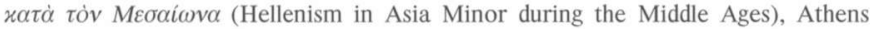

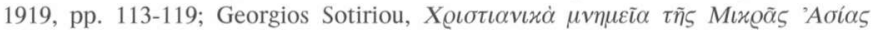
(Christian monuments of Asia Minor), Athens 1920, p. 63; J. Zervos, Hellenism in Pontos, Athens 1920, p. 10; D. Acritas [Michail Argyropoulos], Peuples et races de I'Asie Mineure. Aperçu historique et ethnographique, Constantinople 1922, pp. 3259. On the contrary, crypto-Christianity was not used officially as a legitimizing argument by the Greek delegation during the Peace Conference. In the statistics that were presented, there was no mention of crypto-Christians. See, for instance, E. Vénisélos [Venizelos], La Grèce devant le Congrès de la Paix, Paris 1918.

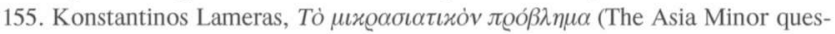
tion), Athens 1918, p. 7, footnote 1.

156. Ibid., p. 30.

157. Ibid., p. 32. 
The transformation of the crypto-Christianity issue was facilitated by European ethnographical research that had taken place in Ottoman territories since the mid-nineteenth century and which described the Empire as a pastiche of races, languages and cultures ${ }^{158}$. In this typically Orientalist project ${ }^{159}$, the emphasis was often put on the essentialization of popular culture, which was seen as including traits that should be dated back to the ancient peoples of the region ${ }^{160}$. In this way European scholars and missionaries ascribed a Christian and Greek origin to the Shiite Kızılbas ${ }^{161}$. Greek intellectuals were not slow to incorporate such methodological assumptions into their work ${ }^{162}$. In so doing, they also appropriated a sense of political-cultural superiority and the hegemonic discourse of European Orientalism.

In 1921, in the midst of the Asia Minor campaign, Lameras made a second decisive step: in a lecture he gave in Athens and afterwards published as a short book, he replaced the various terms borrowed by popular culture (klostoi, Kromlides, Stavriotes, tenesourides) by the general term crypto-

158. The British geographer William Ramsay maintained that it was impossible to draw a "racial map" of Asia Minor. William Ramsay, The Intermixture of Races in Asia Minor. Some of its Causes and Effects, London n.d., p. 56. On racist anthropology in the Balkans see Maria Todorova, Imagining the Balkans, New YorkOxford 1997, p. 123ff.

159. Edward Said, Orientalism, London 1978. On racial, linguistic and anthropological classification see p. $231 \mathrm{ff}$.

160. On survivalist anrthropology see Michael Herzfeld, Anthropology through the Looking-Glass. Critical Anthropology in the Margins of Europe, Cambridge 1987, pp. 7-12. On survivalist ethnography on Anatolia and Hasluck's sceptical attitude toward it see Shankland, "The Life and Times of F. W. Hasluck", in Shankland (ed.), Anthropology, Archaeology and Heritage, vol. 1, pp. 18-30.

161. Compare Pears, op.cit., pp. 268-269. For an analytical approach see Ayfer Karakaya-Stump, "The Emergence of the Kızılbas in Western Thought: Missionary Accounts and their Aftermath", in Shankland (ed.), Anthropology, Archaeology and Heritage, vol.1, pp. 328-353.

162. One of the first was the historian Pavlos Karolidis, a native of Endirlik (Greek: Androniki) in Cappadocia. Karolidis, who had studied in Germany and was later to teach at the Athens University, published in 1886 a book aiming to prove that the Greeks of Asia Minor belonged to the Arian race. The same year he settled down in Athens. Petropoulou describes the book as a "certificate of ideological loyalty" (dilosi nomimofrosynis) which, being an "eterochthon", a Greek from outside

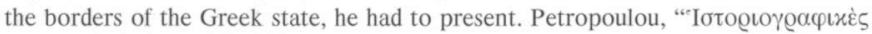

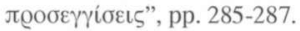


Christians (kryptochristianoi). Under this name he included not only the Kromlides and the Stavriotes, but all heterodox and/or Greek-speaking Muslims of Asia Minor ${ }^{163}$. According to his calculations, the sum of all these populations was more than double the number of Turks in Asia Minor ${ }^{164}$. It is not insignificant that, although Lameras' publication was based on a lecture (hence the rhetorical pathos that dominates the text), the pages are full of footnotes with references to works of European anthropologists, geographers, and historians.

A year later, Georgios Skalieris, a prominent Greek of Istanbul who had settled in Athens ${ }^{165}$, repeated Lameras' new-coined term together with his arguments in his book dealing with the "peoples and races of Asia Minor", probably the best-known example of Greek politicized ethnography on Asia Minor. The following rhetorical question illuminates well one of the author's main points:

"How is it possible for Islam to prevail and how is it possible to incorporate through Islam in the Ottoman pastiche the hundreds of thousands of crypto-Christians who have waited since centuries for the day, on which they shall declare without fear that they are Christians and Greeks?" 166

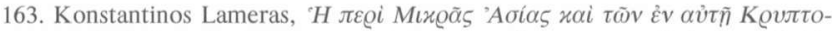
$\chi \varrho \iota \sigma \tau \iota \alpha \tilde{\omega} v \delta \iota \alpha \dot{\lambda} \varepsilon \xi \iota \zeta$ (The lecture on Asia Minor and the crypto-Christians of this land), Athens 1921, pp. 20-27. It is worth comparing Lameras' position to Hasluck's sound methodology: the latter noted in the same year that "the number of crypto-Christians among the heterodox tribes of Asia Minor has probably been considerably exaggerated". Hasluck, "The crypto-Christians of Trebizond", p. 199.

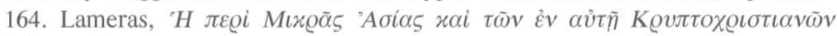
$\delta \iota \alpha ́ \lambda \varepsilon \xi \iota \zeta$, p. 29.

165. Skalieris played an important role in Ottoman-Greek politics in Istanbul until the Committee of Union and Progress gained the upper hand. His father, Kleanthis Skalieris, had been a friend of the unfortunate sultan Murad IV and an advocate of Ottoman-Greek cooperation in a reformed Empire. See the introduc-

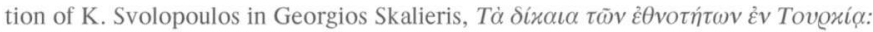
1453-1921 (The rights of the nationalities in Turkey: 1453-1921), Athens ${ }^{2} 1997$ (first edition: Athens n.d.), pp. 9-26.

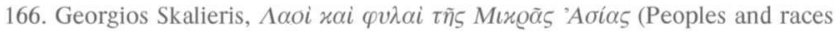
of Asia Minor), Athens 1922, p. 23. 
Lameras was not the first Greek to use the term crypto-Christians in the context of Asia Minor; Notis Botsaris had also used it in his treatise about Greeks in Asia Minor from $1919^{167}$. It is probable that both Botsaris and Lameras adopted the term from the book of the German scholar Karl Dieterich, which was well known at the time ${ }^{168}$. The fact that Dieterich was favourable to Greek national claims contributed to the translation of his book into English and its publication by the American-Hellenic Society in $1918^{169}$.

The American edition included a "brief article on Hellenic Pontus" by Dimosthenis Oikonomidis, a linguist who two years later was to publish his own book on the Pontos, mixing in his turn linguistics, history, geography, ethnography and politics ${ }^{170}$. Oikonomidis, however, did not regard cryptoChristianity as a key issue, neither was he consistent in his use of terms ${ }^{171}$. Despite his obvious national fervour, Oikonomidis did not resort to Lameras' and Skalieris' extravagance. Crypto-christianity in his book was more a localized phenomenon than a method for proving Asia Minor's - or, for that matter, the Pontos'- Greekness.

Contrary to Lameras and Skalieris, Oikonomidis was a Pontic Greek ${ }^{172}$. As a native of Gümişhane and an indefatigable collector of lingustic and ethnographical data from the Pontic countryside ${ }^{173}$, he had a deeper knowl-

167. Botsaris, op.cit., p. 72.

168. Dieterich used the term krypto-Christen. Dieterich, op.cit., p. 13. Four years before him, Edwin Pears had already used the term crypto-Christians referring to the Stavriotes. Pears, op.cit., pp. 266-267.

169. Karl Dieterich, Hellenism in Asia Minor, transl. by Carroll N. Brown, New York 1918.

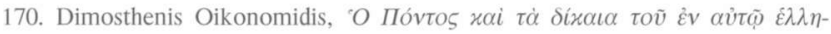

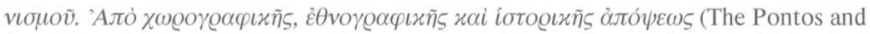
the rights of Pontic Hellenism from a geographical, ethnographical and historical point of view), Athens 1920.

171. In his book the Kromlides and Stavriotes appear as "Christians in secret" (en to krypto Christianoi), p. 76, as klostoi, pp. 75, 110, 148, and as kryptochristianoi, pp. 110, 148-149.

172. Skalieris was from Istanbul and Lameras from Makri (Turkish: Fethiye) in southwestern Anatolia. Evangelidis, op.cit., p. 68.

173. Oikonomidis was the first Pontic scholar to collect linguistic and ethnographical data in a systematic way. It is interesting that, in contrast to Ioannidis before him, he did not refrain from recognizing the significant influence of Turkish on the vocabulary and syntax of Pontic Greek. See Olga Sapkidi, "Oikonomidis, 
edge of crypto-Christianity and knew its limitations well. It is therefore not surprising that he refrained both from attributing a crypto-Christian identity to all heterodox Muslims and from grossly overestimating the number of the Pontic crypto-Christians. Quoting Dieterich's work, he simply stated that their number, which must amount to thousands, could not be exactly estimated ${ }^{174}$.

The contrast between Lameras and Skalieris on the one hand, and Oikonomidis on the other, is indicative. Scholars with a Pontic background tended to regard crypto-Christianity as a phenomenon with a precise locality and character, even at the height of national emotion. In the memoranda submitted in 1918-1919 to the Peace Conference, which were promoting the foundation of an autonomous Greek Pontic state, Konstantinos Konstantinidis ${ }^{175}$ and the metropolitan of Trebizond Chrysanthos maintained that many Pontic Muslims were in fact crypto-Christians ${ }^{176}$. Thus they were able to use crypto-Christianity by capitalizing on the concrete locality of the Kromlides and the Stavriotes. On the other hand, in Lameras' and Skalieris' discourse crypto-Christianity was so vaguely defined that could be attributed to almost anyone almost anywhere, as the need arose.

\section{Conclusions}

The Kromlides, Bryer argued, represented an anomaly within the Ottoman system ${ }^{17}$. I suggest that this "anomaly" appeared after rather than before the Kromlides' declaration of 1857. Crypto-Christianity in the Pontos was created - and projected back in time - by those who presented themselves

Dimosthenis", in Encyclopaedia of the Hellenic World, vol. 1: Asia Minor, http: /asiaminor.ehw.gr/forms/filePage.aspx?lemmaId=8700 (accessed March 30, 2009).

174. Oikonomidis, op.cit., pp. 148-149.

175. Konstantinidis was the president of the Pan-Pontic Congress held in Marseilles in 1918, and the representative of the Pontic Greeks at the Peace Conference. On his activity see Topalidis, op.cit., pp. 254-260.

176. C. Constantinidès [Konstantinidis], Mémoire exposant les aspirations nationales des originaires du Pont-Euxin, Marseilles 1918, p. 3; Chrysanthos, Archbishop of Trebizond, The Euxine Pontus Question. Memorandum submitted to the Peace Conference, Paris 1919, pp.1-6. For further memoranda see Topalidis, op.cit., p. $265 \mathrm{ff}$.

177. Bryer, "The crypto-Christians", p. 33. 
publicly as former crypto-Christians. The Kromlides of 1857 , a social group defined by political action, emerged from a socio-cultural environment characterized by diverse social and economic strategies, syncretism, and multiple identities. This first step from popular culture and local politics towards modern liberal discourse and self-definition was followed by the institutionalization of the tenassur, a category placed awkwardly somewhere in between Islam and Christianity. However, crypto-Christianity was problematic not only for the Ottomans but also for the national intellectuals of Trebizond, who either downplayed the issue or tried to disperse its ambiguity by emphasizing the distinction between "true" and "false" identity.

Towards the end of the century, while the Kromlides intensified their efforts to free themselves from the obligations of their tenassur status, the Stavriotes experienced the uncompromising pressure of the Ottoman Empire, which in its fight for existence sought legitimacy through official nationalism ${ }^{178}$. A few years later, this crisis transformed crypto-Christianity from a local curiosity into a Greek national cause. At the same time, crypto-Christianity was claimed back by the local historians of Santa and Kromni as a foundation myth and a historical mission for their respective homelands. In the late 1910's, crypto-Christianity fuelled the ideological tank of Greek nationalism before and during the Greek expedition in Asia Minor. In the process, crypto-Christianity was transformed again and became a mere ideological issue almost without any precise local reference. At the same time, it was invested with a precise role within national politics, namely to support Greek claims in Asia Minor. With the coining of the term cryptoChristians in Greek, the names used by local popular culture such as Kromlides or klostoi were abandoned in favour of a category that suggested in its name the interpretation of the phenomenon it defined.

Finally, the exchange of populations between Greece and Turkey displaced crypto-Christianity literally and metaphorically. The Greek-Orthodox of Asia Minor, among them the Kromlides and Stavriotes, were subjected to forced migration. The "lost homelands" (chamenes patrides) became localities of the mind, sites of refugee memory and identity ${ }^{179}$, and

178. Deringil, The Well-Protected Domains, p. 47.

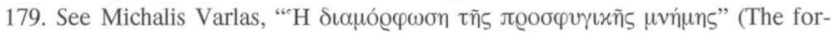

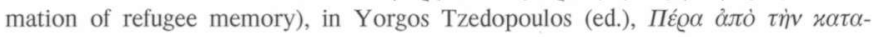


national trauma ${ }^{180}$. At the same time, Asia Minor and Pontic studies developed into distinct sub-disciplines within the framework of Greek history. Crypto-Christianity in the Pontos became a topos of national historiography that supported durable collective myths and perceptions of the past.

Almost all the representations of crypto-Christianity that were analyzed in this article belong to the paradigm of nationalism. Yet their respective interpretations are not only different but also often openly competing. This is hardly surprising, since nationalism - as any other discoursive system - is not monolithic but open to multiple conceptualizations and uses, in accordance with different social and political aims. However, one thing that almost all of the above interpretations share, apart from the essentialization of identity, is the perception of crypto-Christianity as dialectics of continuity and revival. Indeed, I suggest that in Greek national historiography crypto-Christianity - and its opposite, martyrdom, - function often as substitutions of the central concepts of continuity and revival ${ }^{181}$. The confession of the martyr who renounces Islam and returns to Christianity after a time of degradation and shame corresponds to the revival of Hellenism after a long time of enslavement. On the other side, the incorporation of discredited historical periods into Greek national historiography finds its counterpart in the positive evaluation of crypto-Christianity as hidden continuity.

The crypto-Christianity narrative that has prevailed in Greek national historiography has overshadowed by its emphasis on continuity the historicity of its own formation. The present article aims at contributing to a critical reconsideration of the subject, by pointing out the diversity of interpretations as well as the contradictions inherent in the emergence of crypto-Christianity and in its uses for the formation of identity.

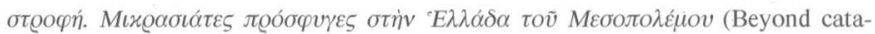
strophe: Refugees from Asia Minor in mid-war Greece), Athens 2003, pp. 148-174.

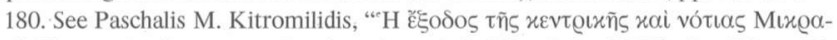

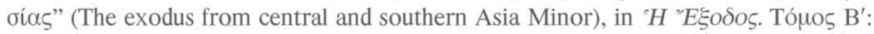

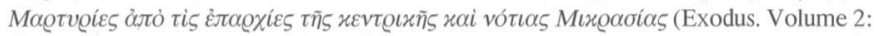
Accounts from the provinces of central and southern Asia Minor), P. M. Kitromilidis (ed.), Athens, Centre for Asia Minor Studies, 1982, pp. $\lambda^{\prime}-\lambda \alpha^{\prime}$.

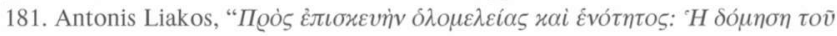

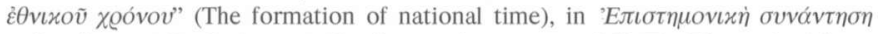

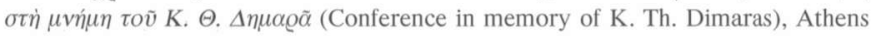
1994, pp. 175-191. 